\title{
YİRMINCİ YÜZYILDA KÜLTÜREL BELLEK VE GELENEĞİN YENİDEN İHYASI BAĞLAMINDA MEHTERHÂNE-İ HÂKÂNî
}

\author{
MEHTERHÂNE-I HÂKÂNÎ WITHIN THE CONTEXT OF CULTURAL MEMORY AND \\ REVIVAL OF TRADITIONAL IN THE 20 th CENTURY
}

Erhhan TEKİN ${ }^{1}$ - Nilgün DOĞRUSÖZ²

\section{$\ddot{O} \mathbf{z}$}

Türk kültür tarihinde askeri müzik geleneği milattan önceki Türk devletlerine kadar uzanmaktadır. Bu gelenek, Tuğ, Tablhâne ve Nevbethâne adlarıyla Selçuklulardan Osmanlılara geçmiştir. Osmanlılarda uzun süre devam eden mehter geleneği 1826 yılında Yeniçeri Ocağı ile birlikte ortadan kaldırılmıştır. II. Meşrutiyet’ten (1908) sonra zuhur eden milliyetçilik ve Türkçülük düşüncelerinden dolayı geleneğin icadı olarak tören ve bayramların yanı sıra geleneğin ihyası olarak 1914 yılında Askeri Müze'de Mehterhâne-i Hâkânî adıyla tekrar canlandırıldı. Batılılaşmanın yoğun etkisinden dolayı eski geleneklere yenileri de eklenerek; kıyafet, çalgılar ve repertuar bakımından, gelenekten görece farklı bir mehter takımı teşekkül etmiştir. Yeni kurulan Cumhuriyetle birlikte Mehterâne-i Hâkân̂̉’nin görevine son verilmiştir.

$\mathrm{Bu}$ makalede, yirminci yüzyllda kültürel ve toplumsal bellek bağlamında Mehterâne-i Hâkânî’nin yeniden canlandırılması ve sonlandırılması hususu, siyasal ve toplumsal nedenleri de dikkate alınarak, tarih, sosyoloji ve antropoloji bakış açıssıla birlikte müzikoloji ve etnomüzikoloji araştırma yöntemleriyle incelendi.

Anahtar Kelimeler: Mehterhâne-i Hâkânî, yeniçeri, Askeri Müze, mehter, gelenek icadı, yeniden canlandırma, kültürel bellek, milliyetçilik, ulus-devlet, Celal Esad, Ahmet Muhtar Paşa

\begin{abstract}
Traditional Turkish military music in Turkish culture history dates back to the era of previous Turkish states BC. This tradition handed down the terms with tuğ tablhane and nevbethâne from the Seljuks to the Ottomans. The tradition of the mehter (janissary band) that continued in the Ottomans was abolished in 1826 with the Janissary Corps. After II. Constitutional (1908), it was reinvented the name of Mehterhâne-i Hâkânî (the band of emperor) in 1914 as the invention of tradition because of the Turkism and nationalism thoughts politically. Due to the intense influence of Westernization, it was reshaped a different mehter team from tradition in terms of clothes, instruments and repertoire by replacing with new ones. The task of it was ended within ten years after Republic founded newly. In this article, to take place collective memory the political and social causes of reviving and dismissing of it were examined through scientific research methods of musicology and ethnomusicology.
\end{abstract}

Keywords: Janissary Band of Emperor, janissary, Military Museum, mehter, the invention of tradition, music revival, nationalism, nation-state, Celal Esad, Ahmet Muhtar Pasha

\footnotetext{
${ }^{1}$ İstanbul Teknik Üniversitesi, erhantekin@itu.edu.tr

2 İstanbul Teknik Üniversitesi TMDK, dogrusozn@.tu.edu.tr
} 


\section{GİRIŞ}

"Mehter", tarihî ve geleneksel Türk askerî müzik topluluğunu temsil eden bir terim olarak hafızalarda yer etti. Günümüzde Türk Silahlı Kuvvetleri Mehteran Birliği ve Kültür Bakanlığı İstanbul Tarihi Türk Müziği Topluluğu Mehter Takımı gibi resmi devlet kurumlarının yanı sıra belediye, polis teşkilatı, başta imam hatip liseleri olmak üzere liselerde ve ilköğretim okulları ve düğün-sünnet, kutlama, açılış vs gibi birçok faaliyetlerde görev alan ticari amaçlı kurulmuş mehter takımlarının sayısı üç yüzün üzerindedir. Günümüzü bu kadar etkileyen mehter müziği ve mehter takımlarının varlığı tarihte milattan önceki Türk devletlerine kadar uzanmaktadır. Uzun bir tarihi ve geleneksel geçmişe sahip olmanın yanı sıra tarihte Orta Asya'dan Anadolu ve Balkanlar'a kadar uzanan geniş bir coğrafik alanda yaygındı. Giderek yaygınlığı ve sayıları artan bu mehter olgusu tarihsel, kültürel, siyasal, sosyal ve iktisadi boyutlara sahip olan bir konu olmaya devam etmektedir. Bu konu müzikal, kültürel, siyasal ve toplumsal işlevlerinden dolayı akademik araştırmaya konu edilmeyi hak etmektedir. Tarihî ve geleneksel bir müzik topluluğu olarak, müzikoloji, etnomüzikoloji, tarih, antropoloji ve sosyoloji gibi disiplinler arası çalışmayı gerektiren bir araştırma alanıdır. İşlevindeki müziksel olgular, formlar, çalgılar, makam ve ritim açısından müzikolojinin çalışma alanına girmektedir. Tarihi, toplumsal ve kültürel yönüyle de tarih, sosyoloji ve antropoloji bilimlerinin yanı sira kültür-müzik ilişkisinden dolayı ${ }^{3}$ etnomüzikolojinin araştırma alanına da girmektedir.

Tarihten günümüze kadar tuğ, tablhane, nevbethane ve mehterhane gibi terimlerle ifade edilen geleneksel Türk askeri müzik toplulukları alanında yazılı kaynaklar ve araştırmalar sınırlı sayıdadır. Mevcut kaynaklar konuya çoğunlukla tarihi bir perspektiften veya hamasi bir bakış açısıyla ele almaktadır. Tarihi kaynakların ve belgelerin yetersizliği bu alanda yapılan akademik ve tarihsel çalışmaları da olumsuz yönden etkilemektedir.

$\mathrm{Bu}$ makalede, siyasi ve toplumsal nedenlerle 1826 'da Yeniçeri Ocağ 1 ile birlikte geleneksel işlevine son verildikten sonra 88 yıl sonra 1914'de siyasi ve toplumsal nedenlerle geleneğin yeniden ihya edilmesiyle yeniden teșkil edilen "Mehterhâne-i Hâkânî", akademik bir bakışla ele alınacaktır. Geleneği yeniden canlandırma hareketi ile birlikte "toplumsal bellek" bağlamında konu ilk defa bu makalede ele alınacaktır.1826 öncesi bir geleneğin temsili olarak geçmişi ve kendisinden sonra geleceği şekillendirmede yani günümüz mehter olgusu üzerinde önemli bir etkiye sahip olmasından dolayı yirminci yüzyılda (1908-1935 arası) yeniden canlandırılan ve Cumhuriyet'le işlevine son verilen Mehterhâne-i Hâkânî mehter takımıyla çalışmamızı sınırladık. Yeniden ihya edilen bu askeri mehter takımı gelenek midir ve gelenek ise geleneksel yapıyla farklılıkları ve benzerlikleri ele alınacaktır.

\section{Geleneğin Yeniden Canlandırmasında Kuramsal Temeller}

On sekizinci yüzyılda Avrupa'da ortaya çıkan Aydınlanma düşüncesinden sonra modernizm ve modernite, yirminci yüzyıl başlarına kadar geleneksel olgulardan kopuşu ifade eden bir dönemdir (Macey, 2001, 257-260). Sosyal ve toplumsal değişim ve ilerlemeyi amaç edinen bu dönemde sanayileşme, rasyonalizm, ulus-devletlerin doğuşu ve kamusal-özel alanlarda değişimler yaşandı (Bilton, 2003, 27).

Aynı dönem içerisinde Fransız İhtilali ile başlayan milliyetçilik, modern ulus-devlet inşası temeline dayalı kültürel kimlik ve devlet arasındaki yasal ve meşru ilişkiyi gösteren ideolojik ve sosyal bir harekettir. Sonsuz bir geçmiş (e) ve ortak kültür üzerine kurulu bir birlik

\footnotetext{
3 Etnomüzikoloji, halk müziği incelemesi, Doğu ve Batı sanat müzikleri, sözlü gelenekle aktarılan çağdaş müzikleri, müziğin başlangıcı, müzikal değişimleri, temsil olarak müzik ve özellikle toplumda müziğin işlevi gibi müziğin kültür olarak ele alındığı konuların incelenmesini kapsamaktadır (Myers, 1992, 3). Aynı zamanda etnomüzikoloji, kültürün müziği içerisinde taşıması bağlamında da antropoloji ve sosyoloji ile disiplinlerarası ilişki içerisindedir (Kaplan, 2005, 37).
} 
ve dayanışma içerisinde kültürel bağlamdan çıkarılan anlam ve sembolleri kendine mal eden milliyetçilik yirminci yüzyılda ana vatan, ulusun babası veya kardeşler temelli metaforik akraba ilişkisine dayalıydı. Milliyet veya ulus kavramı belirli bir sınır içinde tanımlanmaz aksine o; din, kültürel kimlik, ırk, dil ve kültüre göre politik durumla birlikte (ve) kişinin kendini tanımladığı toplumsal şartlardan kaynaklanır. Milliyetçilik, bir nevi politik yasallık olarak, etnik ideolojinin hâkim olduğu bir toplulukta geçmişi antik dönemlere kadar dayanan ulusal devlet anlayışı olarak tanımlanır (Eriksen, 1993, 97-109). Modernite ve milliyetçilik, Fransız İhtilali'nden sonra geleneksel yapılara karşı olarak ortaya çıkan kavramlar olduğu görülmektedir. Bununla beraber milliyetçilik politikaları ile ortaya çıkan ulusalcılık ve modern ulus-devletlerin inşasında eski veya antik dönemlere ait tarihî ve geleneksel yapılar/kavramların yeniden canlandırılması bir zıtlığı veya bir ikilemi göstermektedir.

On dokuz ve yirminci yüzyılda cereyan eden milliyetçilik, ulusalcılık ve ulus-devlet ideolojileri kapsamında yeni inşa edilen devletlerde, birçok yeni kültürel ve tarihsel gibi görünen icatlar ortaya çıktı. Amaç; yeni kurulan ulus-devletlerin veya ulusların aslında daha eski ve ezeli bir geçmişe sahip olduklarını göstermekti. Bu tarihsel görünen geleneksel yapıların yeniden canlandırılmasını Hobsbawm "geleneğin icadı (the invention of tradition)" olarak ifade etti. "İcat edilmiş gelenek/invented ${ }^{4}$ tradition" ifadesini kısa ve belli bir dönem içinde ortaya çıan ve uzun bir tarihi ve geleneği olmayan geleneksel gibi görünen pratikleri kapsamaktadır (Hobsbawm-Ranger, 1992). Ama bu ifade gerçekten tarihi bir geçmişe sahip olan gelenekleri kapsamadığını görmekteyiz. Gelenek, alışılagelmiş sürekliliği olan yerleşmiş yöntem ve pratikler olarak bireyin eylemlerine imkân veren kural ve kaynakların toplamıdır (Ayas, 2015,

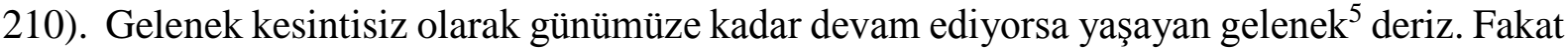
unutulmaya yüz tutmuş eski bir gelenek amacı ne olursa olsun tekrar hayat buluyorsa "yeniden canlandırma" (revived/revival/revitalisation of tradition) ifadesini kullanırız. İngilizce karşılığ olan "revived" kelimesindeki ön ek "re-" tekrar veya yeniden anlamını vermektedir. Dolayısıyla Hobsbawm'ın ifade ettiği icat edilmiş gelenek ifadesindeki icat: "ilk kez yeni bir şey yaratmak" anlamına gelmektedir. İcat kelimesinin İngilizce karşılığı olan invent: bulmak, uydurmak, yaratmak (Url.1) anlamına gelmektedir. Biz bu çalışmamızda unutulmaya yüz tutmuş geçmişte var olan bir geleneği yeniden ortaya çıkarılmasına "yeniden canlandırma" hareketi olarak ifade edeceğiz. Hobsbawm tarafından kullanılan gelenek icad $ı$ veya icat edilmiş gelenek ifadesi, genel olarak, on dokuz ve yirminci yüzyıllarda, toplumsal dönüşümlerde, toplumsal birliği ve beraberliği sağlamak amacıyla süratli bir şekilde ortaya çıkmış, tarihi bir geçmişe sahip olmayan, eski durumları akla getiren yapay ve uydurma pratikleri ifade etmekte kullanılabilir.

Modernizmin ortaya çıkardığı ulus-devlet anlayışının altında yatan milliyetçilik, her şeyden önce birlik duygusu, ortak tarih, yerel ve bireysel farklılıkları ortadan kaldıran bir düşünceye dayalıydı. Milliyetçilik ile yeniden kurulan devletler, tarihlerinde var olan kültürel değerleri yeniden canlandırarak ulusun veya ulus-devletin geçmiş tarihi derinliğini ortaya koymayı amaçlamaktadırlar. Unutulmaya yüz tutmuş tarihi ve geleneksel yapıların belirli bir amaç için tekrar canlandırılması yeniden canlandırma hareketi olarak tanımlanır. Livingstone, yeniden canlandırma hareketini şöyle ifade etmiştir: "müzikal canlandırmalar, modern ve çağdaş bir toplumun yararı için tamamen geçmişte kalan veya yok olduğuna inanılan müzikal bir olguyu yenileştirmek, onarmak veya eski haline getirmeye çalışan sosyal bir harekettir.” Bu noktada müzikal canlandırma hareketini icra edecek topluluk ve bu topluluğun önderlerinin kültürel ve siyasal duruşları ve fikirleri etkin rol oynamaktadır. Yeniden canlandırma hareketinde iki amaç bulunmaktadır. Birincisi, ana akım olan kültüre, kültürel karşıtlık ve bir

\footnotetext{
${ }^{4}$ Invented: İcat edilmiş, uydurma (https://www.seslisozluk.net/invent-nedir-ne-demek/)

${ }^{5}$ Living tradition (https://www.seslisozluk.net/invent-nedir-ne-demek/)

${ }^{6}$ Revived/revitalized/reanimated tradition (https://www.seslisozluk.net/invent-nedir-ne-demek/)
} 
alternatif olarak uygun olmak ve ikincisi de uyanış önderleri tarafından ifade edilen tarihsel değer ve otantiklik üzerine inşa edilen değerler vasıtasıyla daha önce var olan kültürü iyileştirmektir. Canlandırılan uygulama, kültürel ve sosyal açıdan keyif duygusu vermeli ve icra edildiği zaman katılımcılar arasında duygusallık uyandırmalıdır. Kültürel ana akımdan daha çok farklı olmak için uyanış önderleri modern stiller ve elektrikli çalgılar gibi modern teknolojik yenilikleri reddederler (Livingstone, 1999, 66- 69).

Teorik olarak yeniden canlandırma hareketinin meydana gelebilmesi için belirli aşamalardan geçilmesi gerekmektedir. Bu aşamalar: 1. Kararlı ve sürekli değişim 2. Bireysel gerilim ve baskı dönemi 3. Kültürel bozukluk ve çarpıklık dönemi 4. Yeniden canlandırma süreci (Wallace, 1956, 268). Yeniden canlandırma hareketinde tarihi ve kültürel unsurlar, canlandırılan yeni yapının geleneksel temel yapısına benzetilmeye çalışılmaktaydı. Dolayısıyla yeniden canlandırma hareketi içerisinde incelediğimiz askeri mehter takımının da tarihi geleneksel yapısının yeni canlandırılan olgu üzerinde etkisi büyüktü. Ülkenin siyasi, toplumsal ve ekonomik yönlerden zor durumda olduğu bir dönemde gelenek icadı olarak yeniden teşkil edilen Mehterhâne-i Hâkânî bir müzik topluluğu olması nedeniyle bu noktada bir müzikal canlandırma söz konusudur. Gelenek icadı uygulamalar ile müzikal canlandırmalar kültürel karşıtlık noktasında birleşmektedirler. Milliyetçilik ideolojisi doğrultusunda gelenek icadı olarak yeniden canlandırılan Mehterhâne-i Hâkân̂̂, Batılılaşma sonucu işlevine son verilen ve yok olmakta olan bir müzikal canlandırma ile ana akım olan modern kültüre bir karşıtlık olarak ortaya çıkmaktadır.

Devlet eliyle yeniden canlandırılan geleneksel yapıların toplumsal ve kültürel amaçları vardır. Tarihi yeniden kurma pratikleri toplumsal grupların sosyal belleklerinin biçimlendirilmesinde etkili olduğu için (ve) toplumlara yol gösterici bir güce sahip olabilmektedir (Connetron, 2014, 29). Geçmişin yeniden inşası yazılı ve sözlü belge ve tanıklıklara rağmen tahmini olmaktan öteye gidemediğini iddia eden Halbwachs'a göre toplumsal düşünce aslında toplumsal belleğidir (2016, 124, 366). Her toplumda geçmiş, gelenek anlamına gelir. Ortaya gelenek-bellek ilişkisi çıkmaktadır. Assmann bu ilişki hakkında şu tespiti yapmaktadır: "Gelenekler, kültürel anlamın devredilme ve canlandırılma biçimi olarak kültürel belleğin alanına girer". Bellek, hatırlama yoluyla meydana gelir. Hatırlama kültürünün de meydana gelmesi için bir mekân seçilmelidir. Bu mekânda belleğe yerleştirilmek istenen gelenekler bu mekânlarla ilişkilendirilir. Hatırlama kültürleri somut bir mekân ve zamana dayanır. Hatırlama kültürü içerisinde geçmişin geleceğe aktarılmasında müzik sanatı da etkili olmaktadır (Assmann, 2015, 28-63). Hatırlama kültürüyle yaratılan kültürel bellek aslında toplumsal ve kültürel kimliktir.

\section{Gelenek ve Mehterhâne-i Hâkânî}

Türklerde askeri müzik geleneği, Orta Asya'da kurulan ilk Türk devleti Hunlar'a (MÖ 220-MS 216) kadar dayanmaktadır. (Gazimihal, 1955, 1; Erendil, 1992, 2; Vural, 2011, 58). Hunlar döneminde ilk askeri müzik topluluğu olarak bilinen "tuğ" takımlarında yırağ (zurna), borguy (boru), tümrük (davul), küvrük (kös) ve çeng (zil) denilen çalgılar bulunurdu (Gazimihal, 1957, 5; Vural, 2011, 58; Vural, 2013, 24). VIII. yüzyılda yazılmış Orhun yazıtlarında "tuğ" kelimesine rastlanmaktadır (Sanal, 1964, 1). Dîvânü Lugati't-Türk (1074)'de geçen "tuğ/tug" kelimesi bayrak, sancak, anlamlarının yanı sıra hakanın huzurunda çalınan kös ve davul anlamına da gelmektedir. Bu gelenek, Selçuklulara kadar devam eder. Selçuklularda askeri müzik takımlarına "tablhâne ve nevbethâne" denilirdi (Ertuğ, 2010, 334). Daha sonra Osmanlı Devleti'nin ilk yıllarından itibaren yaklaşık olarak iki yüzyıl kullanılan "tablhâne" ve "nevbethâne" terimlerinin yerine Yavuz Sultan Selim (1470-1520)'den sonra "mehterhâne" denildi (Konyalı, 1942, 50). 1826 yılına kadar devam eden geleneksel Türk askeri müziği, 
Yeniçeri Ocağı'ndan hemen sonra kaldırıldı (Çoruhlu, 1989, 107; Sanal, 1993, 296; Özcan, 2003, 549).

1826 yılında Yeniçeri Ocağı ile birlikte görevine son verilen geleneksel Türk askeri müzik toplulukları olan mehter takımları farklı dönemlerde farklı terimlerle adlandırılırdı. Osmanlılar zamanında Alem mehterleri, Cemaat-i mehterân-ı alem, Mehterân-ı tabl ü alem-i hassa, Tabl - alem-i hassa veya Hassa tabl ü alem neferâtı gibi ifadeler kullanılmaktaydı (Sanal, 1964, 8). Fakat 1826 yılında ortadan kaldırılan padişahlara ait mehter takımlarına Mehterhâne-i Hâkânî veya Mehterhâne-i Hümâyun denilirdi (Pakalın, 1993, 446; Eralp, 1999, 742; Altınölçek, 1999, 754). Kuruluşu, Fatih Sultan Mehmet (1432-1481) zamanına kadar giden Mehterhâne-i Amire, çadır işleri ile ilgili Mehterhâne-i Hayme ve askeri bando ile ilgili Mehterân-ı Tabl-ı Âlem gibi iki kurumdan oluşmaktaydı. 1826 yılında Yeniçeri Ocağ kaldırıldıktan hemen sonra aynı yıl Ekim ayında bu kuruma bağlı olan Mehterân-ı Tabl-ı Alem bandosuna Mehterhâne-i Hâkânî veya Mehterhâne-i Hümâyun denilirdi (Yaramış, 2013, 32). Mehterân-ı Tabl-ı Alem devletin tüm resmi mehter takımlarının bağlı olduğu bir kurumu ifade etmekteydi. Tarihte Mehterhâne-i Hâkânî ise padişaha ait bir mehter topluluğunu temsil etmekteydi. Daha sonra 1914 yılında Askeri Müze'de yeniden canlandırılan askeri müzik topluluğuna da Mehterhâne-i Hâkânî denildi (Erendil, 1992, 29). Gelenek ve yeniden ihya edilen iki kurumun aynı adla ifade edilmesi gelenekte isim sürekliliğini göstermekteydi. 19 ve 20 yüzyıllarda milliyetçilik ideolojisi doğrultusunda gelenek icadı uygulamalar doğrultusunda yeniden ihya edilen Mehterhâne-i Hâkânî, temsili bir olgu olarak öykündüğü geleneksel bir tarihi geçmişe sahipti. Mehterhâne-i Hâkânî, terim olarak, tarihte padişah veya hükümdara ait mehter takımı anlamına gelmekteydi. Geleneğin İhyası olarak 1914 yılında yeniden teşkil edilen Mehterhâne-i Hâkânî', geleneği temsil eden kültürel bir anlam taşımaktaydı.

1826 y1lında son bulduktan sonra, 88 yıl gibi uzun bir unutma ve unutulma döneminden sonra toplumsal, siyasal ve kültürel amaçlarla yeniden canlandırılan mehter takımı aslında geleneğin kurgusal bir temsiliydi. Dolayısıyla "geleneğin ihyası" söylemi ile yirminci yüzyılda icat edilmiş olan Mehterhâne-i Hâkânî, milattan önceki Türk devletlerinden itibaren 1826 yilına kadar devam eden bir geleneği temsil etmekteydi. Geçmiş bir geleneği temsil etmesi bakımından Mehterhâne-i Hâkânî icat edilmiş uydurma bir gelenek değildi, unutulmaya yüz tutmuş var olan bir geleneğin yeniden canlandırılmasıydı.

\section{Osmanlıların Yirminci Yüzyılın Başlarındaki Siyasi ve Sosyal Durumu}

On sekizinci yüzyıldan yirminci yüzyıla kadar Osmanlı Devleti siyasi, askeri, iktisadi ve içtimai alanlarda oldukça ciddi problemler yaşadı. Bu problemlerin en önemlisi, 1698 yılında Karlofça Anlaşması ile ilk kez toprak kaybedilmesiydi. Bu durum, devlet içerisinde siyasi, askeri, iktisadi ve toplumsal alanlarda çeşitli sorunlara yol açtı (Çınar, 2006, 360). Dolayısıyla Osmanlılarda reformların başlamasına neden oldu. Reformların başladığı bu dönem çalışmamızın kuramsal olarak yeniden canlandırma hareketinin kararlı durum ve koşulların başladığı aşamayı göstermektedir. Devam eden Batılılaşma hareketleri kapsamında, Osmanlı siyasal ve toplumsal yapısında yabancı kurumlar ve uygulamalar görülmeye başlandı 1793 yılında III. Selim'in orduda başlattığı 1slahat hareketleri ile Batılılaşma, II. Mahmut (18081839) döneminde de oldukça gerilimli bir şekilde devam etti. Yeniden canlandırma hareketinin ikinci aşaması olan bireysel ve toplumsal gerilim ve baskı dönemi başlattı. Bozulan Yeniçeri Ocağı ve Bektaşi Dergâhları 1826 yılında kaldırıldı. Daha önceleri ekonomik ve askeri yönde başlatılan ve devam eden reformlar nedeniyle geleneksel kurumların işlevlerine son verilmekteydi (Karpat, 2008, 77-83). Devam eden önemli siyasi ve askeri olayları ve ortaya çıkan başlıca sorunları şu şekilde sıralayabiliriz: 1830 yılında Yunanistan'ın bağımsızlı̆̆ı, Mısır sorunu (1833), Tanzimat Fermanı (1839), Islahat Fermanı (1856), 1878 Rusların Edirne'yi işgal etmeleri (Avcı, 2006, 467-505). Yirminci yüzyıla kadar yaşanan toprak kaybının yanı sıra 
bir takım siyasi ve ekonomik sorunlar padişahı ve devleti zor durumda bıraktı. Siyasal, toplumsal ve ekonomik olarak zor durumda olan devleti ve toplumu kurtarmak için alınan/uygulanan önlemler Batılılaşmayı toplumsal bir baskı haline getirdi. Bu uygulamalar kuramsal yaklaşımda kararlı ve sürekli değişim dönemini kapsamaktaydı.

Yirminci yüzyılın ilk çeyreğinde meydana gelen siyasi, askeri ve ekonomik olaylarla Osmanlı Devleti, rejim tartışmalarının yapıldığı bir döneme girdi. 24 Temmuz 1908'de II. Meşrutiyet ilan edildi ve yapılan seçimler sonucu Türkçülük ideolojisine sahip olan İttihat ve Terakki Partisi (ITP) yönetimde etkili olmaya başladı. İstanbul'da anayasal düzene karşı yapılan 31 Mart ayaklanması ITP'ne duyulan bir tepkiydi. ITT'nin Selanik'te hazırladığ Hareket Ordusu isyanı bastırdı ve bu durum İTP'nin daha da güçlenmesini sağladı. İTP'nin iktidarda söz sahibi olduğu 1908-1913 yılları arasında çok ciddi toprak kayıpları yaşandı. Bu kayıpları şu şekilde sıralayabiliriz: Avusturya Bosna-Hersek'i ve Yunanistan Girit adasını işgal etti; Bulgaristan bağımsızlığını ilan etti; 1912 yılında Trablusgarp ve 12 ada İtalya'ya bırakıldı. 1912-1913 Balkan Savaşları ile Osmanlı Devleti, siyasi ve askeri tarihinde büyük değişimlerin meydana geldiği bir döneme girdi. Bulgarlar Edirne'yi işgal ettikten sonra İstanbul yakınlarında Çatalca'ya kadar ilerledi. Rusların desteğiyle Balkanlar'da yayılan milliyetçilik düşüncesi sonucu birçok millet bağımsızlığını ilan etti (Akşin, 2013, 45-83). Son olarak Arnavutlar ve Araplar da özerklik ve bağımsızlık peşindeydi. Arnavutlar birkaç kez isyan etti ve nihayet Balkanlar'da yaşayan gayrimüslim toplumlar bağımsızlıklarını ilan edince coğrafik olarak Osmanlı'dan kopan Arnavutlar da bağımsızlıklarını ilan etti. Aynı şekilde Araplar da İngiliz ve Fransızların tahriki ve teşviki sonucu 1908 yılında isyan ederek 1911 yılında da bağımsızlıklarını ilan etti (Kodaman, 2002, 179). Görüldüğü gibi 1914 yılına kadar Osmanlı tebaasında yaşayan tüm milletler bağımsızlıklarını elde etmişlerdi. Devleti kurtarma mücadelesi Osmanlı tebaasında sadece Türkler tarafından yapılmak zorundaydı.

1912-1913 yılları arasında Balkan Savaşları, Osmanlı'da siyasi düşüncenin değişmesinde önemli rol oynadı. İlk olarak II. Mahmut döneminde (1808-1839) başlayan "Osmanlıcılık" düşüncesi, farklı unsurları Osmanlı Devleti altında birleştirmeyi amaç edinmekteydi. Fakat Balkanlar' da cereyan eden milliyetçilik hareketleri sonucu birçok millet bağımsızlığını ilan ettiğinden dolayı bu düşünce sadece Müslüman Türkler arasında bir süre varlığını sürdürebildi (Özcan, 2007, 487). İkinci olarak "İslamc1lık", II. Abdülhamit döneminde (1876-1908) İslam birliğini sağlamak ve hilafet makamını korumak için devletin resmi ideolojisiydi. II. Meşrutiyet dönemine kadar Batı sömürgeciliğine karşı çareyi İslamiyet’ten arayan bir düşünceydi. Garpçılık veya Batıcılık, Tanzimat döneminde egemen olan Osmanlıcılık ile devletin kurtuluşunu hedef alan bu düşünce daha sonra İttihat ve Terakki Partisi'nin temel düşünce ve ideolojisiydi. Diğer önemli iki düşünce de "Türkçülük ve Turancılık" idi. II. Meşrutiyet'in ilanından sonra Balkanlar ve Rumeli'nin elden çıkmasıyla Osmanlıcılık düşüncesi son bulduktan sonra Türkçülük düşüncesi Türk ulusçuluğuna dönüşerek yayıldı (Akşin, 2013, 83-87). 1914 yılında Rusya'nın dağılacağı yönünde haberler, tüm Türk toplumlarını bir çatı altında birleştirmeyi hedef alan Pantürkizm ve Turancılık fikirlerinin doğmasına neden oldu. 1913 yılında da Türk-İslam temelli bir düşünce içerisinde "Türkleşmek, İslamlaşmak, Muasırlaşmak" şeklinde cereyan etti (Hanioğlu, 2012, 554). Ana akım düşüncenin Türkçülük-İslamcılık olarak değişmesi, Türk milliyetçiliğini daha da öne çıkardı. Türk milliyetçiliği, Türk kimliğini ve Türk kültürünü Osmanlı öncesi devirlere kadar götürerek ezeli bir geçmişi ortaya çıkarma eğilimindeydi.

\section{Teşebbüs}

Gelenek İcadı Uygulamalar ve Yeniçeri Mızıkasının Canlandırılmasında İlk

Yirminci yüzyıl başlarında zor durumda olan devleti ve milleti kurtarmak için siyasi ve toplumsal adımlar atılması gerekiyordu. Fransız İhtilali, Modernizm ve Milliyetçilik akımları, 
başta Avrupa olmak üzere yeni ulus-devletlerin oluşmasında etkin rol oynamaktaydı. $\mathrm{Bu}$ süreçte yeni kurulan ulus-devletlerin ulusal kimliklerini oluşturmak için gelenek icadı geçmiş uygulamalara başvurdukları bilinmektedir. "İcat edilmiş gelenek" ifadesini kullanan Hobsbawm bu ifadeyi şöyle tanımlamaktadır: "Bu terim gerçekten icat edilmiş ve formel düzlemde kurumsallaşmış gelenekleri olduğu kadar, kolayca izi sürülemeyecek bir şekilde kısa ve belirlenebilir bir zaman diliminde belki de birkaç yılda ortaya çıkmış olan ve büyük bir hızla yerleşmiş gelenekleri kapsamaktadır”. Amaç; toplumsal birlik ve beraberlik duygusu yaratarak vatanseverlik, sadakat ve görev bilinci oluşturmaktır. Dolayısıyla icat edilmiş gelenekler yeni inşa edilen ulus, ulus-devlet, milliyetçilik, ulusal semboller ve tarihi olgularla ilintili olmalıdır (Hobsbawm, 2006, 4-17).

Aslında tarihi ve geleneksel pratiklerin 19 ve 20 yüzyıllarda yeniden icat edilmesi veya canlandırılmasının var olan millet, toplum ve ulus-devletler için belirli amaçları vardı. Keleş, Batı'da 19. yüzyılda, geçmişin şimdiden kullanılmasıyla geleceği tasarlayan tinsel bir yapıya sahip olan tarihsel algının görevini şu şekilde ifade etmektedir: "tarih ve tarihi malzeme, tarihçi için sadece geçmişi hatırlatan bir olgu değil, ona geleceğin sinırlarını belirleme ve sırlarını çözme imkânı verecek de bir malzeme olmuştur”. Kısacası tarihçiyi geçmişi yeniden kurgulayarak geleceği inşa eden biri olarak tanımlamaktadır (Keleş, 2007, 41).

Osmanlı topraklarında milliyetçilik sonrası esen Türkçülük düşüncesi doğrultusunda Mehterhâne-i Hâkânî öncesi bazı gelenek icadı uygulamalar yapıldı. Siyasi ve toplumsal bir amaca yönelik olarak toplumsal yapıya sokulmak istenen gelenek icadı diğer uygulamalar da Türk milliyetçiliği düşüncesine dayanmaktaydı. II. Meşrutiyet sonrası ortaya çıkan milli günler ve milli bayramlar olarak gördügümüz gelenek icadı faaliyetlerin siyasi ve toplumsal nedenleri vardı. İktidarda bulunan İttihat ve Terakki Partisi'nin Türkçülük politikaları bağlamında milli birlik ve beraberlik duygularını geliştirmek için Ocak 1909'da Osmanlı Meclis-i Mebusan'da milli günler üzerine tartışmalar yapıldı. $\mathrm{Bu}$ görüşmelerin konusu, Osmanlı Devleti'nin kurulduğu günü anmak için Osmanlı Istiklal Günü ve II. Meşrutiyet'in ilan edildiği 10 Teтmиz'u milli törenlerle kutlanmasıyla ilgiliydi. Uzun tartışmalardan sonra 10 Temmuz'un milli bayram olarak kutlanması yönünde karar alındı (Yılmaz, 2009, 87). İlk kutlamalarda Osmanlı tebaasında farklı unsurları bir araya gelmesiyle kolektif bilinç yaratarak rejimin ve devletin devamlılığı amaç edinilmişti. 10 Temmuz kutlamalarında birlik mesajları verilerek, askeri törenler, ulusal marşlar, bayraklar ve vatanseverlik konuşmaları ön plana çıkmıştı (Yamak, 2008, 340). Toplumda duygusal ve entelektüel dayanışma sağlanarak toplumu bir arada toplamak ve tutmak için o topluluğun kökenleri ile ilgili epik olaylar ve kahramanlıklar daima yenilenerek yeniden biçimlendirilmektedir (Smith, 2007, 110).

Mehterhâne-i Hâkânî 'nin gelenek icadı olarak yeniden canlandırılmasında etkisi olduğunu düşündügümüz diğer gelenek icadı kutlama törenleri, Istanbul'un Fethi Kutlamaları ve Osmanlı'nın şanlı geçmişini anmak için Yevm-i İstiklâl-i Osmanı̂ denilen Osmanlı İstiklâl Günü'ydü.

İstanbul'un fetih kutlama törenleri İTP'nin Türkçülük politikaları bağlamında ilk defa 1910 yılında kutlandı. 1914 yılında ise daha coşkulu bir şekilde kutlandı. Bu kutlamalarda Ayasofya'dan hareket eden kafilenin önünde Osmanlı'yı temsil edercesine yeniçeri kıyafetli üç kişi yürütüldü (Engin, 2003). Amaç; İstanbul'un fethinde çok önemli rol oynayan yeniçerileri temsil etmekti. Tarihte bildiğimiz gibi yeniçerilerle birlikte savaş alnında onlara cesaret veren mehter takımları da vardı. Kaynaklar 1453 yılında İstanbul'un fethinde yeniçerilerle birlikte savaş alanında 300 kişilik bir mehter takımından bahsetmekteydi (Şahiner, 1993, 18). 1453 yılında Fatih Sultan Mehmet tarafından İstanbul kuşatıldığı zaman kuşatmanın ilk gününden itibaren fethedildiği güne kadar savaş alanında mehter takımı sürekli çalmaktaydı (Pertusi, 2004, 242-254). İstanbul'un fetih kutlama törenleri modern çağda gelenek icadı bir hadise 
olarak ortaya çıktı. Balkan Savaşları nedeniyle zor durumda olan ülkeyi kurtarmak için toplumda milli birlik ve beraberlik duygusu yaratmak amaç edinilmişti (Çoruk, 2016, 80). İstanbul'un fethi kutlama törenlerini icat edilmiş bir gelenek olarak tanımlayabiliriz. Çünkü 1453 yılında fethedilen İstanbul için ilk kutlamalar II. Meşrutiyet sonrası yapılmaya başlandı. Hobsbawm'ın ifade ettiği “icat edilmiş gelenek” çok kısa bir süre önce ortaya çıkan ve hızlı bir şekilde toplumsal yapıya yerleşen gelenekler olarak tanımlanmaktadır $(2006,2)$.

30 Aralık 1913 yılında da Osmanlı İstiklal Günü kutlanmaya başlandı. Bu kutlama törenlerinde Osmanlı'nın Türkler tarafından kurulduğu, Türk-İslam sentezine ve Türklük bilincine vurgu yapıldı (Uzun, 2009, 129-140). Osmanlı İstiklal Günü, Selçuklu Sultanı tarafından Osmanlı Devleti kurucusu olan Osman Bey'e gönderilen hâkimiyet alametlerinin ulaştığı gün olarak kabul edilip kutlanmaktaydı (Yılmaz, 2009, 88). 1289 tarihli bir fermanla Söğüt ve civarını Osman Bey'e veren Selçuklu Sultanı, fermanla birlikte Osmanlılarda mehterin ilk atası olarak kabul edilen davul, zil, nakkare ve boru gibi çalgılardan oluşan küçük bir tuğ takımı da gönderdi (Sanal, 1964, 5; Konyalı, 1942, 4). Bu tarihi bilgi bize Osmanlıların kuruluşunda geleneksel Türk askeri müzik topluluğunun olduğunu göstermektedir. 1914 yılında yapılan kutlamalarda tören alayının önünde gelenek icadı olarak yeniçeri kıyafetli canlı mankenler yürüdü (bkz. resim: 1). Osmanlı İstiklal Günü kutlamaları icat edilmiş bir gelenektir. Çünkü 1289 yılında kurulan Osmanlı Devleti için ilk kutlama yine II. Meşrutiyet sonrası yap1ld1.

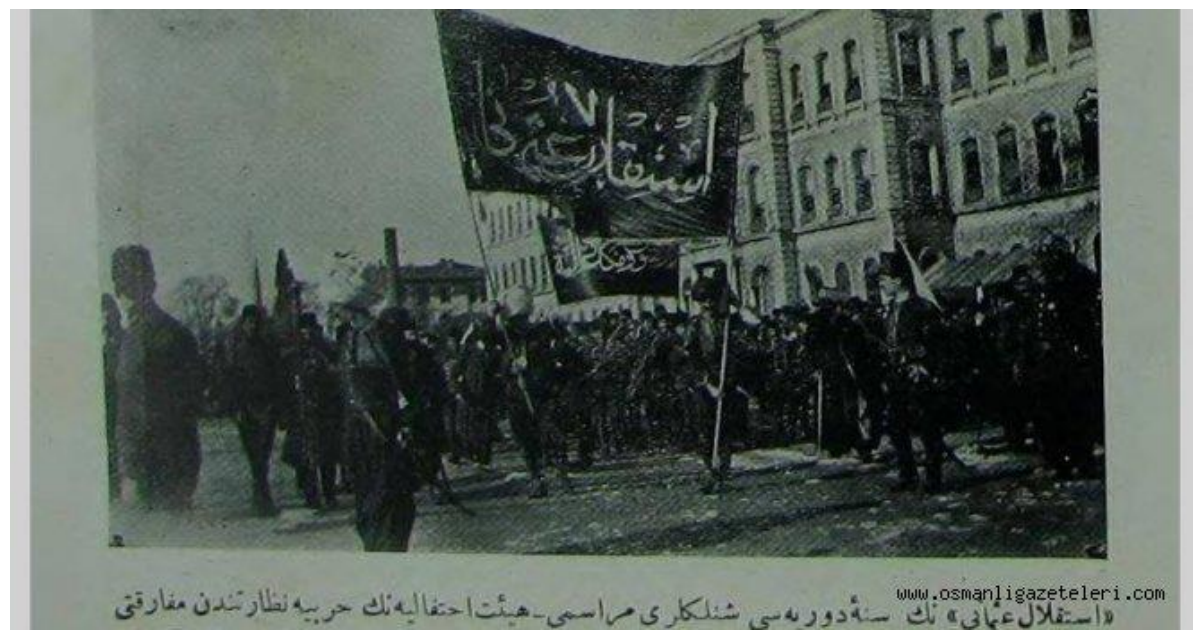

Resim 1: Osmanlı İstiklal Günü Kutlamaları (1914) Url-2.

$\mathrm{Bu}$ törenlerde kullanılan yeniçeri kıyafetleri ile ilgili çalışmalar da gelenek icadı bir uygulama olarak Yeniçeri Ocağı'nın kaldırılmasından sonra ilk defa 1857 yılında yapıldı. Bu tarihte Londra'da açılan bir müzede yeniçeri kıyafetleri sergilendi. 1866 yılında ise Sultanahmet'te alçı ve balmumundan yapılmış mankenler üzerinde yeniçeri kıyafetlerinin sergilendiği "Yeniçeri Müzesi" açıldı (Mülayım, 2009, 182-184). Yeniçeri kıyafetleri, Yeniçeri Müzesi ve anma törenleri toplumsal bellek uygulamalarıdır. Dile getirici bir özelliğe sahip olan törenler yinelenebilir olmalarından dolayı geçmişin kesintisiz olarak devam ettiğini düşündürür. Anma törenlerinde anımsanan aslında bir kimlik veya bir kültürdür (Connetron, 2014, 77-122). Gelenek icadı olarak yeniden canlandırılan bu anma törenleri ve bayramların amacı 1912-13 yılları arasında sadece Anadolu toprakları üzerinde yaşayan Türkleri, devleti kurtarmak için bir araya getirmek için uygulanan kültürel bellek faaliyetleri olarak değerlendirebiliriz. Yapılmakta olan bu anma ve kutlama bayram ve törenlerinin tarihte cereyan ettiği durumlarda mehter takımlarıyla birlikteliği mehterin yeniden kurulmasında bir hatırlama etkisi yarattığı düşünülebilir. 10 Temmuz, Istanbul'un Fethi Kutlamaları ve Osmanlı İstiklal Günü gibi icat edilmiş geleneksel uygulamalar ve milli bayramlar, bu bayramlar için yapılan 
törenler ve bu törenlerde yeniçeri kıyafeti giydirilmiş canlı mankenler mehter takımlarının canlandırılmasına etki eden pratikler olarak değerlendirilmektedir. Bu pratikler hatırlatma olgusu yaratmada etkili oldular.

Yeni icat edilen bu geleneksel kutlama günlerinde tarihte rol almasından dolayı eksik olan tarihi unsur mehter takımıydı. Bu konuda da ilk adımı Celal Esad (Arseven) (1875-1971) attı. Celal Esad, Türk sanat tarihinin önde gelen araştırmacılarında biri, ansiklopedi yazarı, ressam, idareci, şehir planlamacısı, tiyatro ve senaryo yazarı, rejisör, arkeolog, öğretim üyesi, sözlükçü, belediyeci ve değişik müzik aletlerini çalabilen çok yönlü bir kişiliğe sahipti (Eyice, 1991, 398). Celal Esad, yazdığı tiyatro eserlerinde Osmanlıcılık fikrine karşılık İslamiyet öncesi Türklük bilincine vurgu yapmaktaydı (Büyükarman, 2008, 137). Celal Esad, Türk sanat ve mimarlık alanlarında da 1906-1907 yıllarında yaptığı çalışmalarla Osmanlı sanatı ve mimarlığının Bizans, Arap ve Acem sanatlarında ayrı olarak ortaya koymak için çalışmalarda bulundu (Cephanecigil, 2008, 98). O, tiyatro ve mimarlık alanlarında yaptığı çalışmalarda gördüğümüz gibi Türkçülük düşüncesine sahip bir şahsiyetti. Tarihi Orta Asya'ya dayanan Türk kültür ve sanat unsurlarına eğilim göstermesi ve müzik alanında da ilgi ve bilgisinin olması onu mehter müziğini yeniden canlandırmaya yönelten nedenlerden sayılabilirdi.

Celal Esad, 1911 senesinde "Türk Musîkîsi ve Yeniçeri "mehter” Mûzikâsı Hakkında Mütâlaat” adlı bir risale yayınlayarak milli ve öz bir Türk musikisine dikkat çekmekteydi. Bu risalenin ilk sayfasında yeniden canlandırmak istediği yeniçeri mehter mûzikâsı için esas aldığı kaynak Ârif Paşa'nın (1808-1865) telif ettiği Mecmûa-i Tesâvir' di. Ârif Paşa'ya göre Türk musikisi, Avrupalılarca Bizans, Arap ve İran gibi Doğu müziklerine benzetilmekteydi. Nasıl ayrı bir Türk kimliği var ise bu müziklerden ayrı olarak bir Türk musikisi de vardı. Yerli ve Avrupalı müzik otoriterlerinden milli ve eski Türk havalarının Anadolu'da toplanarak bir an önce Batı musikisi ilmiyle tetkik edilmesini ve hatta çok sesli düzenlenmesini istemekteydi. O, kaybolma tehlikesiyle yüz yüze gelen musikimize, musiki severlerin veya musikişinasların dikkatini çekmek için bir konser düzenlemeyi planlıyordu. Bu konser sayesinde birilerinin dikkatini çekerek musikimizi kurtarmak ve dünyaya tanıtmak arzusundaydı (Celal Esad, 1911, 2-5).

Bu konu doğrultusunda Rauf Yekta (1871-1935), Şehbal dergisinde "milli musikimizin ihyası için neden ciddi ve esaslı bir teşebbüs vuku bulamıyor" diye musikişinaslara ve devletin resmi kurum ve yetkililerine seslenerek ilgili kişilerin dikkatini çekmeye çalışırken bu teşebbüsün ilk defa hususi bir şahıs tarafından yapılmasından duyduğu memnuniyeti ifade etmekteydi. Rauf Yekta, makalesinde şehrin ilim ve fenninde pek tanınan muhterem Celal Esad ile eskiden beri arkadaşlıklarının olduğunu ve bir sohbette kendisine düşünce ve projesini anlatan Celal Esad ve onun yaptığı detaylı çalışmalar ve masraflar hakkında şunları söyledi:

"Yeniçerilerin mûzikâsını ihya etmek istiyorum. Hani Ârif Paşa merhumun "Kıyâfet-i Atika-i Osmanı̂" namındaki eserinde kartpostalların üzerine nakledilen yeniçeri bandosu yok mu ya? İşte onu aynen canlandırmak fikrine düştüm. Bir hayli masraf-1 ihtiyariyle bando efradının bütün elbise ve serpuşlarını müceddeden (yeni baştan) imal ettirdim. Bandonun kullanacakları alet-i musikiyesinin bazılarını alet-i cedideden (yeni aletler) olacak ise de bunda da eski alete en müşabbih (benzer) ses verenler ittihab (hibe) ettim. Yakında bir konser vereceğiz. Bu bandoya çaldıracağım en nefis asar-1 milliyeye (milli eserler) Garp musikisine vukuf-u yelisi bulunan bir üstat tarafından bas konuldu. Bildiğimiz "Rast Peşrevi” öyle bir hale geldi ki dinlemekle doyulmuyor. Selim-i Sâlis (III.) Hazretlerinin "Suz-i dilara" fasl-1 meşhuru da programımıza dâhildir. Bu asr-1 bedianın (nadide ve güzel eser) böyle tarihi bir şekil ve kıyafete haiz bir bando tarafından icrası cidden büyük bir tesir husule getiriyor. $\mathrm{Bu}$ teşebbüsümle musikimizin ne kadar mesut terakki olduğuna dair Şarklılara da Garplılara da bir fikir-i imal verebilirsem kendimi bahtiyar edeceğim" (Rauf Yekta, 1912, 473). 
Celal Esad, bu düşüncelerden sonra eski yeniçeri mızıkası denilen mehterhâneyi yeniden ihya etmek için yaptığı hazırlıklardan sonra 29 Şubat $1911^{\prime} \mathrm{de}^{7}$ İstanbul Tepebaşı Tiyatrosu'nda bir konser düzenledi (Kösemihal, 1939, 21; Oransay, 1973, 231; Tuğlacı, 1986, 24). İşte bu hazırlıklar ve konser, geleneksel Türk askeri müzik tarihinde önemli bir dönüm noktasını oluşturmaktaydı. Mehter tarihinde yeniden canlandırma süreci bu hadiseyle başlamıştı.

Rauf Yekta, Celal Esad'ın bu teşebbüsünü çok beğendi ve kendisini teşvik etti. Rauf Yekta, hüsnüniyet ve samimiyetle Türk musikisinin ihyası için verilecek olan konser masrafları ve hizmetlerini ödeyen Celal Esad'ı takdirle karşılamasına rağmen bazı hususlarda da eleştirmekten geri kalmadı. Rauf Yekta, klasik Türk müziği eserlerinin çok sesli hale getirilmesi ve belki de bu çok seslilikten dolayı eserlerin makam hususiyetlerini tamamen kaybettiğini ifade etmekteydi (Rauf Yekta, 1912, 13; Kösemihal, 1939, 21). Bunun en büyük sebebi tabi ki ilk teşebbüs olması nedeniyle eksiklikler vardı ama asıl neden makam hususiyetini verebilecek Türk müziği çalgılarının yerine onlara nispeten yakın olduğu düşünülen Batı çalgılarının kullanılmasıydı. Bu çalgılar; obua, klarnet, piyano ve trombon gibi bando çalgılarıydı. Zor olan bu teşebbüsü Gazimihal'de şu satırlarla ifade etti: “...ölmüş müesseseleri restore edip yaşatmak- tarihteki rolleri ne kuvvette olursa olsun- maddeten güçtür." Celal Esad, nota bilen zurna icracısı bulamadığından dolayı zurnaya en yakın obua ve klarnet çalgılarını kullandı (Gazimihal, 1955, 28). Bu takımın 1911 yılında müze konser salonunda da bir konser verdiğini görmekteyiz (Çoruhlu, 1989, 107). Gelenek icadı olarak yeniden canlandırılan yeniçeri muzikasının bu ilk teşebbüsünde Batı müzik çalgıları ve Batı armonisi kullanıldı. Bu durum Batılılaşmanın geleneksel yap1 ve kültürlerin içine ne kadar işlediğini göstermekteydi. Hobsbawm, gelenek icadı uygulamalarda bu durumu şu şekilde ifade etmekteydi: "Eski malzemelerin gayet yeni amaçlara yönelik olarak yeni türde icat edilmiş geleneklerin inşasında kullanılmasıdır. Bazen yeni gelenekler eskilerine yamanarak oluşturulabilir" (Hobsbawmn, 2005, 7). Yeniden canlandırma hareketini bu ilk aşamasında yeni gelenekler eski geleneksel bir yapıya eklenerek gerçekleştiğini görmekteyiz. Celal Esad tarafından teşkil edilen mehter takımının Askeri Müze bünyesinde konser verdiğini tahmin etmekteyiz (bkz. Resim 2). Ayrıca resimde Batı çalgılarından trombon, obua ve klarnetten başka kös yerine de timpani kullanıldığını da tespit etmekteyiz.

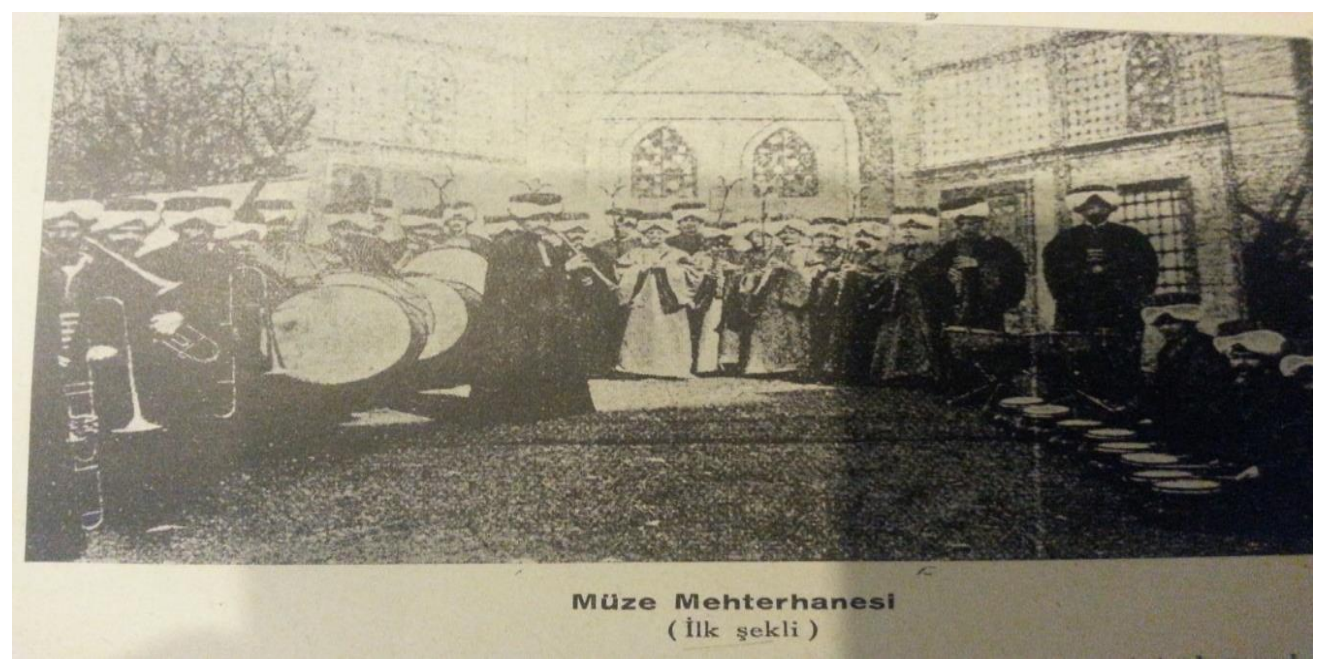

Resim 2: Celal Esad Arseven tarafından kurulan ilk yeniçeri muzika takımı (Kösemihal, 1939, 21).

\footnotetext{
${ }^{7}$ Gültekin Oransay bu konser tarihini 16 Şubat 1328- 29 Şubat 1912 olarak vermektedir
} 


\section{Askeri Müze Müdürü Ferik Ahmet Muhtar Paşa ve Mehterhâne-i Hâkânî (1914)}

Celal Esad'ın bu teşebbüsünden sonra mehter takımının Müze-i Askeri'de teşkil edilmesi yönünde adımlar atıldı. Müze Müdürü Ahmet Muhtar Paşa ${ }^{8}$ (1861-1926) yeni bir mehter takımı teşkil edilmesinde önemli rol oynadı. Ahmet Muhtar, 1906 yılında ferik rütbesine yükseldi ve orduya silah temini amacıyla Avrupa ülkelerine gittiği sirada Avrupa müzeleri hakkında da araştırmalarda bulundu. II Abdülhamid'in görevlendirmesiyle önce Yıldız Sarayı'nda kurulan bir silah müzesine atandı ve II. Meşrutiyet'ten sonra Aya İrini'de kurulan müzeye atandı. Yaşanılan bazı sıkıntılardan sonra Mahmut Şevket Paşa (1856-1913) tarafından tekrar 1908 y1lında yeniden müzeyi kurmakla görevlendirildi. Ahmet Muhtar, o devirlerde Müze-i Askerî Osmanî bünyesinde yeniçeri mehter takımını resmi devlet eliyle yeniden canlandırmak için çalışmaları başlattı. Celal Esad tarafından ilk defa düzenlenen konserde görevli olan icracılar, Askeri Müze bünyesinde değerlendirilerek Topkapı Sarayı'nda 1914 yılında Mehterhâne-i Hâkânî adıyla yeni bir mehter takımı teşkil edildi (bkz. Resim: 3). Bu takım haftada iki gün konser vermeye başladı (Kösemihal, 1939, 22). Kültürel bellek oluşturmada mekânlarında etkisi vardır. Askeri Müze, Yeniçeri Kıyafetleri Müzesi ve Mehterhâne-i Hâkânî̀nin yeniden canlandırıldığı bir yer olarak önemli bir hafıza mekânıdır. Hafizanın ortaya çıktığı kalıntılar, arşivler, mezarlıklar, bayramlar, anıtlar ve kutsal yerler vs gibi yerlerle birlikte geleceği geçmiş üzerinden şekillendiren müzeler hafıza mekânları olarak sayılmaktadır (Nora, 1994, 23). Tasouji, toplumsal bellek bağlamında toplumda tarih bilinci uyandıran müzeleri şu şekilde tanımlamaktadır: "müzeler: ulus inşasına hizmet eden ve vatandaşlık kimliğine sadık kalan bireylerin yetiştirilmesinde kamusal ve tarihi bir araç olarak kullanirlar" (Tasouji, 2015, 131).

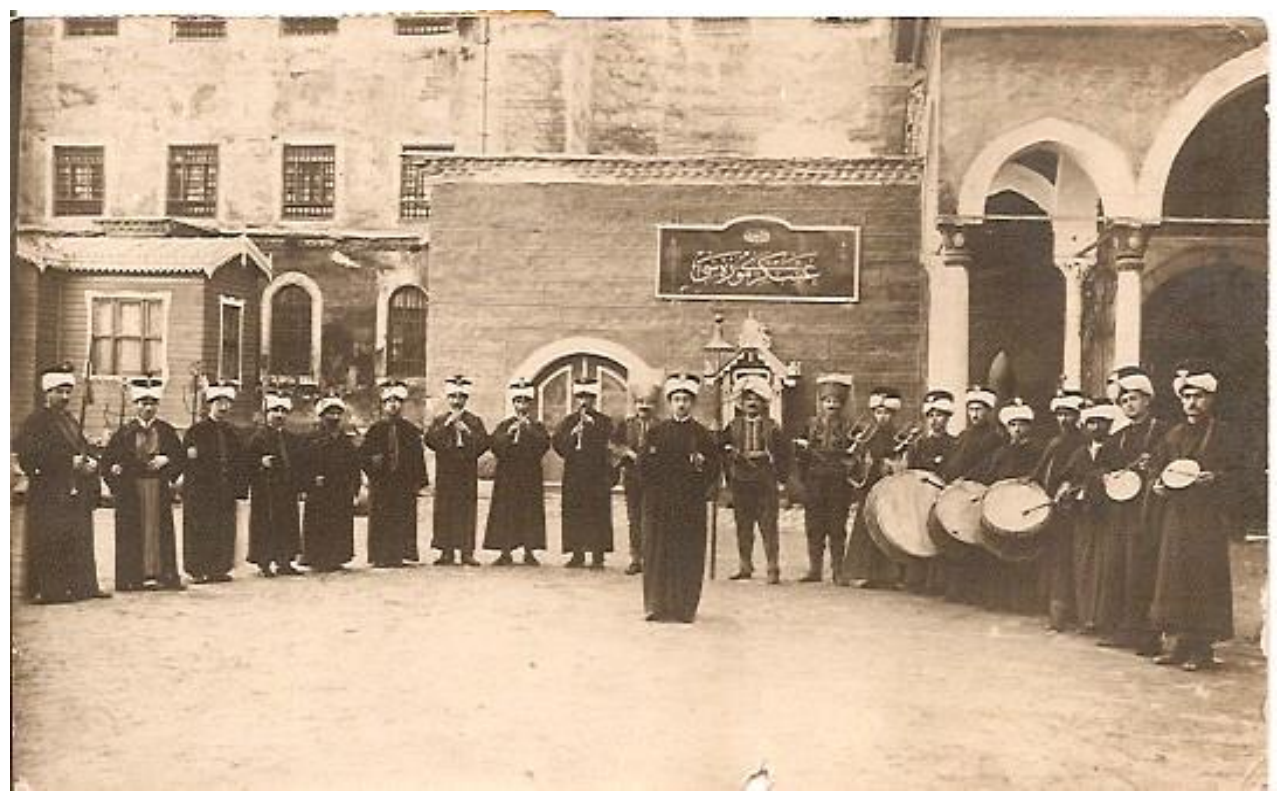

Resim 3: Mehterhâne-i Hâkânî, Topkapı Sarayı Askeri Müze önünde konser düzeninde (Askeri Müze Fotoğraf Arşivi).

Topkapı Sarayı'nda o tarihlerde Askeri Müze olarak hizmet veren Aya İrini binası önünde konser düzeninde gördügümüz Mehterhâne-i Hâkânî, geleneksel 1826 öncesi mehter takımlarına göre farklılıklar göstermekteydi. Ârif Paşa'nın resmettiği (Resim 4) Mehter takımı 1826 öncesi mehter geleneği ile karşılaştırıldığı zaman tören vaziyeti ve çalgıların, yer ve sayılarında gelenekle uyuşmayan farklılıklar görülmektedir. Tarihi ve geleneksel bir yapının

\footnotetext{
${ }^{8}$ Askeri Müze müdürü ve Mehterhâne-i Hâkânî takımını kuran Ferik Ahmet Muhtar Paşa (1861-1926) ile asker, siyaset adamı ve 1912'de sadrazam olan Gazi Ahmet Muhtar Paşa (1839-1919) karıştırılmamalıdır.
} 
yeniden ihya edilmesi sonucu otantik yapıyla olan bu farklılıklardan dolayı yeni takımı kurgusal bir gelenek olarak tanımlayabiliriz.

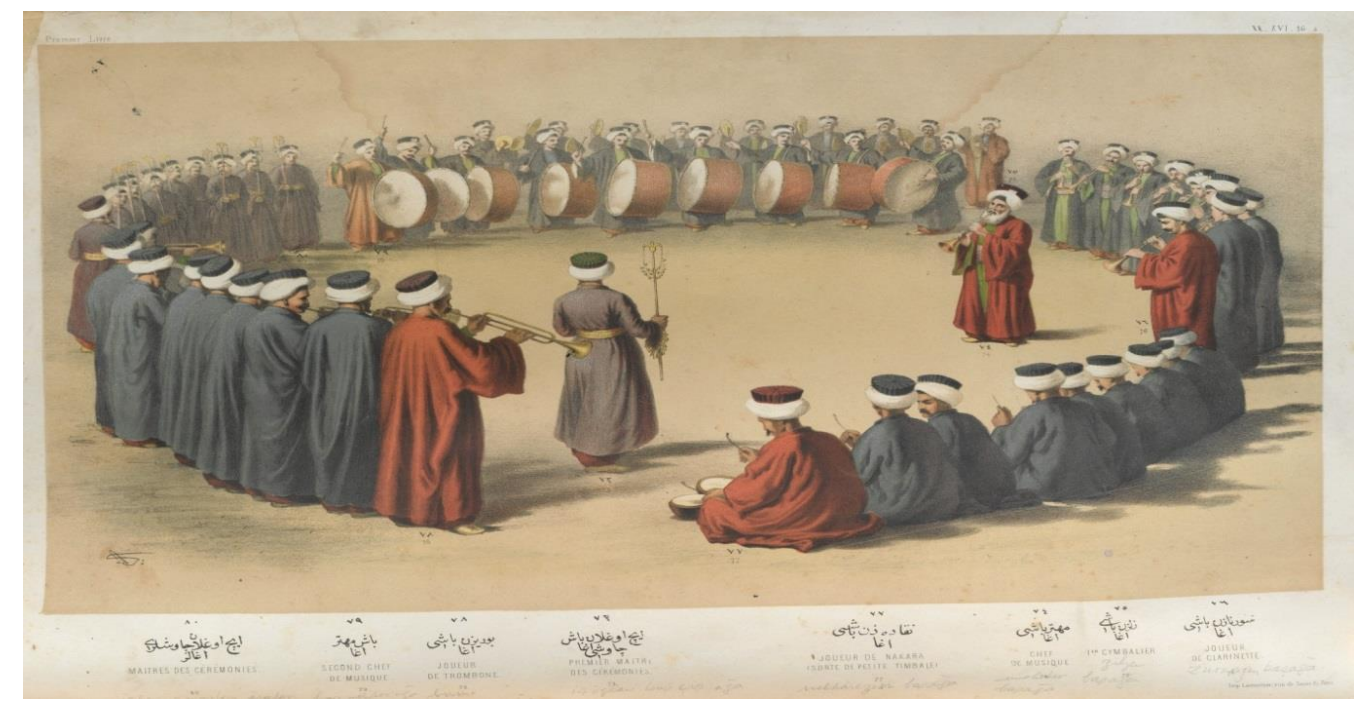

Resim 4: Ârif Paşa tarafından resmedilen geleneksel mehter takımı. (Askeri Müze Kütüphanesi)

Törende tam bir daire şeklinde duran geleneksel mehter takımında çevgân sayıları ve kıyafetleri, mehterbaşı olarak ortada duran iç oğlan başçavuş ve serzurnazen olarak görev yapan mehterbaşı ağasının yeri, nakkârezenlerin vaziyetleri, çalgı gruplarının yer ve sıraları yeni teşkil edilen takımla benzememekteydi. Eskiden içoğlanı başçavuşlardan oluşan çevgâniler, diğer sazendeler ile aynı sayıda olmasına rağmen yeni takımda diğer çalgı gruplarının iki katı kadardı. Çevgâniler, eskiden boru ve davul arasında bir yerde dururken yeni takımda hilal şeklinde duran takımın sol baş tarafında sıralanmaktaydı. Çevgâni kıyafeti hakkında kaynaklarda farklılıklar vardı. Ârif Paşa ve Mahmut Şevket Paşa resmettiği çevgâni kıyafetinde sırtına giydiği kaputun üstüne kuşak bağlamıştı. Kuşağın arasında ve ön tarafta bir kama bulunmaktaydı (Ârif Paşa, 1863, 15; Mahmut Şevket, 1909, 88). Çevgân grubu kıyafeti diğer bir kaynakta ise şu şekilde izah edilmekteydi: "Elindeki çevgânları musikadaki gibi sallamakla mükellef olan bu başçavuş kolları kapaklı ve kapağın iç tarafı müsellesül (üçgen) şekil kesilmiş dar kollu, orta yerinde beş rakamı tarzında bir işareti haiz müstakil-ül şekil elvanı havi sarı renkli entari giyer, başına yeşil renkde destar kavuk sarar, ayağına sarı mest pabuç iktisa ederdi” (Mehmet Zeki, 1916, 76). Yeni teşkil edilen takımda çevgâniler diğer sazendelerle aynı kıyafeti giymekteydi.

Çalgıların konser düzeninde sıralanışları da gelenekten farklıydı. Geleneksel takımda başmehter ağa olan zurnazen başı ve içoğlan başçavuş elinde çevgâni ile takımın ortasında durarak takımı idare ederken yeni takımda zilzen başı elinde zili ile takımın ortasında yer almaktaydı. Yeni takımda gelenekten farklı olarak tarihte yeniçerileri temsilen tuğ taşıyan yeniçeri kıyafetli canlı mankenler de bulunmaktaydı.

Kıyafetler açısından baktığımız zaman başa giyilen kavuk, cübbe ve yemeni çevgân grubu hariç benzetilmeye çalışılmıştır. Geleneksel mehter kıyafetleri hakkında Ahmet Cevat şunları yazmaktadır: "Mehterbaşı kırmızı renkli cübbe, başına destar kavuk sarar ve ayaklarına kırmızı çakşır ve sarı mest pabuç giyerler. Diğerleri başlarına destar kavuk, arkalarına siyah veyahut mor veya lacivert çukadan biniş ve ayaklarına çuka veya bezden dizlik ve mest pabuç giyerler" (Ahmet Cevat, 1882, 171). 1914 yilında teşkil edilen Mehterhâne-i Hâkânî ile geleneksel mehter takımı kıyafetleri arasında genel bir benzerlik sağlanmaya çalışılmışsa da renk ve şekillerde farklılıklar olduğu da görülmekteydi. 
Aslında kaynakların yetersizliğinden dolayı geleneksel mehter takımları hakkında da detaylı bir tespit yapmak oldukça zordur. Bu karşılaştırmada kaynak olarak esas aldığımız Ârif Paşa tarafından resmedilen mehter takımı geleneğin en son durumunu göstermesi bağlamında ele alacağımız en önemli ve tek kaynaktır. Yukarıda bahsedildiği gibi Celal Esad tarafından başlatılan ilk teşebbüste de Ârif Paşa tarafından çizilen resimler ve bilgiler örnek alınmıştı. Ama karşılaştırma yapıldıktan sonra Celal Esad tarafından yapılan söylemlerin icra edilen eylemlerle uyuşmadığını görmekteyiz.

Geleneksel mehter takımı ile Ahmet Muhtar Paşa'nın kurduğu Mehterhâne-i Hâkânî̀yi karşılaştırırken, tarihçi ve müze uzmanı İbrahim Hakkı Konyalı, Ârif Paşa'nın çizdiği resimde serpuş ve kıyafetlerin renklerinin hakiki renkler olduğunu söylemekteydi. Bununla beraber yeni teşkil edilen Mehterhâne-i Hâkânî için de şu eleştiriyi yapmaktaydı: “Askeri Müze'nin eski müdürlerinden Ahmet Muhtar Paşa mehteri ihya etmek istemiş ve halefleri de onun izinden yürümüşler. Yaptıkları takım kitabe, ananeye, nizama uymayan manasız bir şeydi" (Konyalı, 1942, 62- 64).

1914 yılında yeniden teşkil edilen mehter takımı hakkında yaptığımız araştırmalarda elde ettiğimiz fotoğraflarda takımın devamlı bir değişim içerisinde olduğunu tespit ettik. Ârif Paşa'nın resmettiği geleneksel mehter takımında çevgân, boru, zurna, davul, zil ve nakkare çalgıları bulunmaktaydı. Oysa elde ettiğimiz bazı resimlerde Mehterhâne-i Hâkânî takımında bu çalgılarla birlikte farklı olarak bir dönem ney çalgısının da kullanıldığını tespit ettik. Daha sonra çekilen fotoğraflarda rastlanmadığı için ney çalgısının çok kısa süreliğine kullanıldığı tahmin edilmektedir.

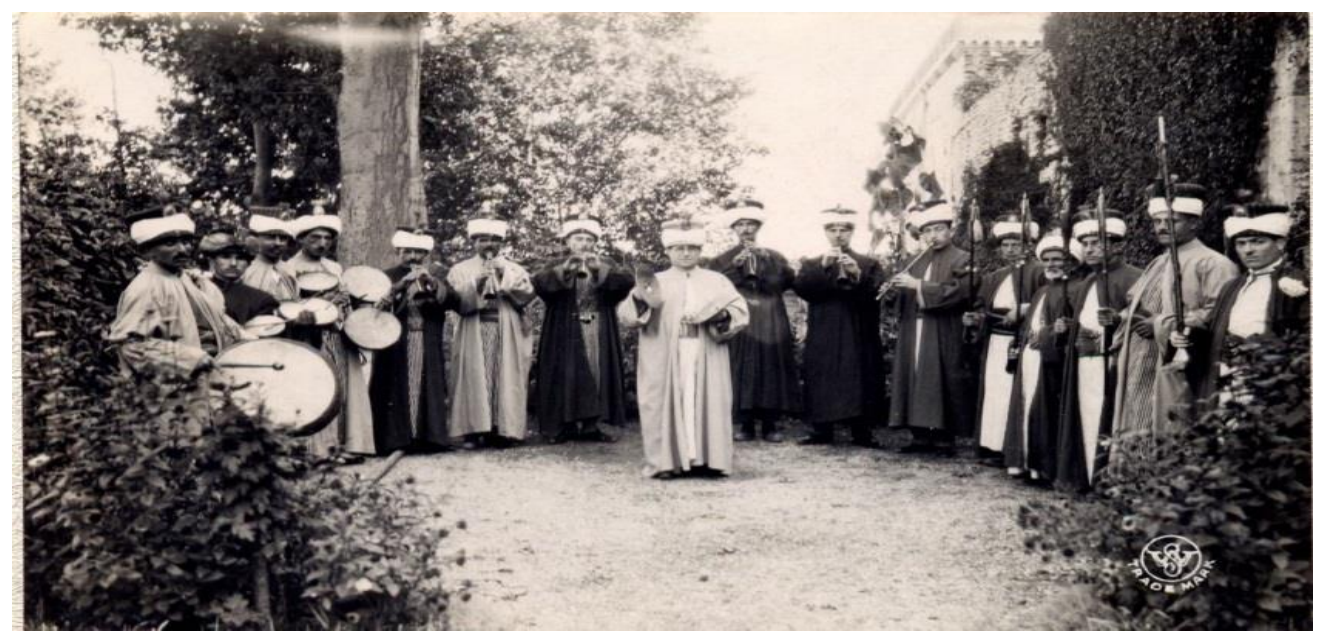

Resim 5: Mehterhâne-i Hâkânî konser düzeninde (Askeri Müze Kütüphanesi)

O yıllarda çekilen fotoğraflar incelendiği zaman Mehterhâne-i Hâkânî, kurulduktan sonra tören şekilleri, kıyafet ve çalg1 sayılarında değişim devam etmekteydi. Mehterbaşı Hasan Tahsin Parsadan (1900-1954), İstanbul'un 500. fetih törenleri hakkında 17 Aralık 1952 tarihinde Vakit gazetesi muhabiri ile yaptığı röportajda, 1914 yılında kurulan Mehterhâne-i Hâkânî hakkında hatırlarını anlatırken, Ferik Ahmet Paşa tarafından ihya edilen takımın sayısı 40 kişiden fazla olmadığını bildirmiştir (Koçdemîr, 1952). Hasan Tahsin Parsadan, Osmanlı'da ilk musiki mektebinin kurucusu ve birçok mehter marşlarıyla ünlü Muallim İsmail Hakk1 Bey'in (1866-1927) öğrencilerinden (Güçtekin, 2014, 6) olup bu mehter takımında klarnet icracısı olarak görmekteyiz (bkz Resim 6). Resimde giyilen kıyafetler ve davulların ölçülerinin farklı oldukları görünmektedir. 


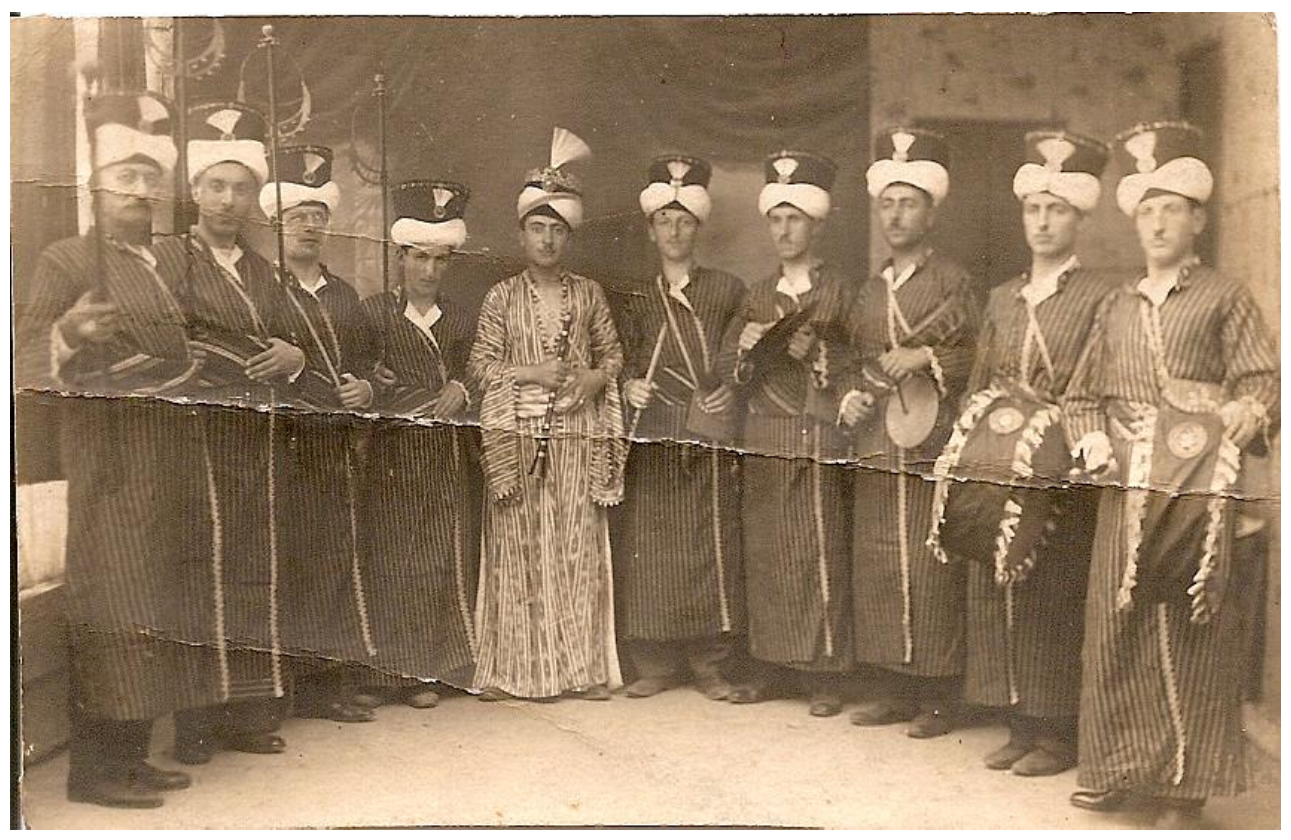

Figür 6: Klarnet icracısı Hasan Tahsin Parsadan ve küçük bir mehter takımı (Askeri Müze).

Yukarıda bulunan bu resim incelendiği zaman dört çevgâni, bir klarnet, bir ney, bir zil, bir nakkâre ve iki küçük davul mevcuttur. Mehterhâne-i Hâkânî takımında klarnet çalgısının da kullanıldığını bu resimde görmekteyiz. O yıllarda Askeri Müze bünyesinde sergileme mekânları ve kütüphanenin yanı sıra bir adet de sinema bulunmaktaydı (Çoruhlu, 1989, 107). $\mathrm{Bu}$ sinema salonunda mehter takımı konserler vermekteydi (Url-3). Diğer resimlerde görülmeyen bu kıyafet ve çalgılarla oluşturulan mehter takımının sinema salonunda konserler verdiği düşünülmektedir.

1914 yılında resmi kuruluşunu Askeri Müze bünyesinde tamamlayan Mehterhâne-i Hâkânî mehterbaşılığına Eyyubi Ali Rıza Şengel (1879-1953) getirildi (Özcan, 2003, 549; Eralp, 1999, 296). Ayrıca İsmail Hakkı Bey (1865-1927) ve Hoca Kazım Uz (1873-1943), mehterbaşı Şengel ile birlikte yeni yaptıkları bestelerle mehter repertuvarını zenginleştirmeye alıştılar (Tuğlacı, 1986, 26). Yeniden canlandırma ile teşkil edilen mehter takımı askeri kurgu üzerine inşa edildiğinden dolayı çoğu mehter marşı olarak bilinen yeni bir repertuar ile tarihsel repertuardan kopuş yaşanmıştı (Öztürk, 2010, 1). Haydar Sanal tarafından farklı kaynaklardan derlenerek elde edilen geleneksel mehter repertuarı (Sanal, 1964, 131-281) ile yeni teşkil edilen takımın repertuarını oluşturan "Mehterhâne-i Hâkânî Notaları" arasında hiçbir benzerlik yoktu (Ayas, 2015, 227). Yeni mehter takımı kendi repertuvarını da günün kültürel ve siyasi yapısına uygun olarak yeniden oluşturmuştu.

\section{Mehterhâne-i Hâkânî 'nin Kapatılması}

Birinci Dünya (1914-1918) ve Kurtuluş Savaş1 (1919-1922) gibi büyük askeri ve siyasi hadiselerden sonra yapılan ülkede meydana gelen rejim değişikliği ve sonrası ilan edilen yeni Cumhuriyet, Mehterhâne-i Hâkânî gibi geleneksel kurumları olumsuz yönden etkiledi. Kaynakların çoğundaki ifade Mehterhâne-i Hâkânî mehter takımının 1935 yılında aslına uygun olmadığı gerekçesiyle dönemin Milli Savunma Bakanı Zekai Apaydın (1884-1947) tarafından kaldırıldığı yönündeydi (Eralp, 1999, 297; Vural, 2016, 32; Sanal, 1964, 291; Tuğlac1, 1986, 27; Altınölçek, 1999, 754). Fakat yaptığımız araştırmalar sonucunda Mehterhâne-i Hâkânî̀nin faaliyetlerine 1935 öncesi hatta Cumhuriyetin ilk yıllarında son verildiğini tespit ettik. Mehterhâne-i Hâkânî takımının görevine son verilme nedeni hakkında farklı diğer bir görüş daha vardı. Şahiner, Mehterhâne-i Hâkânî̀nin kapanış nedenini "padişahlığın alameti” olarak 
gösteriyordu (Şahiner, 1993, 28). Kaldırılan saltanatı hatırlattığı için olabilirdi. Fakat Askeri Müze tarihi üzerine yapılan bir çalışmada Shaw; mehter takımının görev ve konserlerine son verildiği tarihi 1935 'den önce olduğunu ve 1923 yılından itibaren konserlere son verildiğini iddia etmektedir (Shaw, 2003, 197). Bu iddiayı destekleyen diğer bir kaynak daha vardı. Harp zamanında Topkapı Sarayı'nda haftada iki gün konser veren mehter takımının faaliyetlerine son verildiğini yazan 1922 basımlı Âlem-i Musiki adlı dergisinin basım tarihinden yola çıkarak Cumhuriyetin ilk yıllarında faaliyetlerine son verildiğini anlamaktayız. Bu hususta Muhammed Baha Âlem-i Musiki'de şu bilgileri vermekteydi: "Bu tarihi takım harp senelerinde Topkapı Sarayı'nda haftada iki gün ihya eyledi .....fakat bunda da devam edilmedi bu da nihayet söndü bitti" (Muhammed Baha, 1922, 59). Derginin yayınlandığı tarih itibariyle 1920 veya 1921 yılında faaliyetlerine son verildiği kesinleşmektedir. Mehter takımının görevine son verildiği tarih hakkında Mehterbaşı Hasan Tahsin Parsadan (ö. 1954) tarafından bir gazeteye verilen röportajda da şöyle denilmekteydi: "Milli mücadele sonunda Refet Paşa (1881-1963), İstanbul'a gelince mehter takımı lağıv oldu." (Koçdemir, 1952). 19 Ekim 1922'de TBMM adına İstanbul'a gelen Refet Bele Paşa Haydarpaşa Gar'ında sonra Sultanahmet Meydanı'nda yapılan karşılamada mehter takımının icra ettiği İzmir Marşı ile karşılandı (Url-4). Yeni kurulan Türk Devleti, 1 Kasım 1922'de saltanatı ve 3 Mart 1924'te de Halifelik makamını kaldırdı (Akşin, 2013, 174-186). Saltanat ve Hilafet Makamı kaldırıldıktan sonra bir Osmanlı askeri bandosu olarak görülen mehter takımının, 1923 sonrası faaliyetlerine son verildiği görüşü daha güçlü bir görüş olarak karşımıza çıkmaktadır. Yukarıda kaldırılma sebeplerinden biri olarak verdiğimiz saltanat alameti olarak görülmesi, saltanat kaldırıldığı yıllarda mehterin faaliyetlerine son verildiği kuvvetle muhtemeldir. Arşivlerde ve kütüphanelerde özellikle 1923-1935 yı1ları arasına ait olan gazete ve dergilerinde yaptığımız araştırmalar neticesinde bu mehter takımının 1923 sonrası konser faaliyetleri hakkında her hangi bir belge, fotoğraf veya habere rastlamadık. Bu kaynaklar Mehterhâne-i Hâkânî takımının görevine 1923 yılı civarlarında son verildiğini kuvvetli bir şekilde göstermektedir.

Saltanat 1922 'de kaldırıldığına göre saltanat alameti sayılan bir unsurun 1935 yılı gibi 13 yıl sonra kaldırılması uzak bir ihtimal olarak görülmektedir. Bu konuyla ilgili olarak TBMM ve ATASE arşiv ve kütüphanelerinde yaptığımız araştırmalarda 1935 yılında kapatıldığına dair her hangi bir belgeye de rastlamadik.

\section{SONUÇ}

Türk tarihinde geleneksel askeri müzik, milattan önceki devirlerde Orta Asya'da kurulan Türk devletlerine kadar gitmektedir. Mehter geleneği zaman ve mekân olarak Osmanlı'nın sınırlarını aşmaktadır. Orta Asya'dan Balkanlar'a kadar uzanan bir coğrafyada farklı dönemlerde farklı terimlerle ifade edilerek Osmanlılarda geleneksel askeri müzik toplulukları genel anlamda mehter ya da mehterhâne terimleriyle ifade edilmiştir. Osmanlılarda özellikle yeniçerilerle birlikte savaş alanlarında yer alması ve en son olarak 1826'da Yeniçeri Ocağı ile birlikte ortadan kaldırılmasından dolayı yeniçeriliğin bir parçası olarak hafızalarda yer etmiştir. Yirminci yüzyıla gelindiğinde Batılılaşma, toplumun her katmanına nüfuz etmiştir. Geleneksel kurumlar ve yapılar yıkılmıştır. Dünyada yayılan milliyetçilik ideolojisinden dolayı Osmanlı'ya bağlı milletler bir bir bağımsızlıklarını ilan ederek kendi ulus devletlerini kurdular. Balkan ve Arap coğrafyasında yaşanan toprak kayıpları ve düşmanın İstanbul önlerine kadar gelmesiyle devlet ve millet zor durumdaydı. Siyasi ve toplumsal çareler aranıyordu. Devleti kurtarmak için hâkim olan siyasi düşüncelerden Osmanlıcılık ve İslamcılık yirminci yüzyılda etkinliğini kaybederek Türkçülüğe doğru yönelim başladı. Devleti kurtarma görevi bir tek Türklere kaldı. Türkçülük düşüncesi ana akım olmakla beraber Osmanlıcılık ve İslamcılık da Türkler arasında etkisini sürdürmekteydi. Türkçülük düşüncesi İttihat Terakki Partisi'ni iktidara getirdi. Türkçülük fikrini savunan İttihat Terakkiciler, vatanı kurtarmak için Batıcılıktan yanaydılar. İktidarda etkin olan İttihat Terakkiciler Türk halkına, Türk kültür ve 
geleneklerine yönelerek Türk milletini bir amaç etrafında toplayarak vatanı kurtarmak istiyordu. Çok hızlı bir şekilde yayılan Türkçülük ve Türk milliyetçiliği düşüncesi etrafında halkı bir araya getirmek için gelenek icadı yeni uygulamalara gidildi. İște Mehterhâne-i Hâkânî bu gelenek icadı uygulamalarından biridir.

$\mathrm{Bu}$ dönemde uygulanan milli bayramlar ve milli günler ile halk arasında birlik beraberlik ve vatanseverlik duygularını arttırmak için eski geleneklere başvuruldu. Bu yeni icat edilen gelenekler Mehterhâne-i Hâkânî'nin yeniden canlandırılmasında etkili oldu. Gelenek icadı olarak Yeniçeri Müzesi, 10 Temmuz bayramı, İstanbul'un fethi ve Osmanlı Bağımsızlık Günü hadiseleri mehter takımını hatırlatan uygulamalardı. Mehterin kurulması kaçınılmazdı. Balkanlar'dan Orta Asya'ya kadar yaşayan tüm Türkleri bir çatı altında birleştirmeyi amaçlayan Türkçülük düşüncesi doğrultusunda tüm Türkleri bir araya getirmek düşüncesi olan Türkçülük ve Turancılık ideolojilerine uygun bir niteliğe sahipti. Geleneğin yeniden canlandırılması uygulamalarına en uygun örtüşen geleneksel Türk askeri müziği ve mehter olgusuydu. Milliyetçilik akımından dolayı ortaya çıkan uluslar ve ulus devletler geleneksel ve halk kültürlerine yöneldiler. İktidarda olan İttihat ve Terakki Partisi parti politikası doğrultusunda yaptığı gelenek icadı uygulamalarla en çok örtüşen Mehterhâne-i Hâkân̂̀’yi yeniden canlandırmaktı. Türk tarihi nasıl milattan önceki Türk devletlerine kadar gitmekteyse geleneksel Türk askeri müzik geleneği de aynı tarih ve coğrafyaya kadar gitmekteydi. Yeniden teşkil edilen mehter takımıyla Türklük olgusunun ezeli bir geçmişe sahip olduğu ifade edilmekteydi.

Mehter, bünyesinde hem Osmanlı'yı aşan bir Türk kültürünü, hem de Osmanlı ve yeniçeriliği simgelemektedir. Daha da ötesi bir müzik topluluğu olmanın yanı sıra Türklükle özdeşleşmiş bir kültürel kimlik anlamı da taşımaktadır. Batıcılık, modernizm ve modernite gibi ideolojiler geleneksel yapılar ve kültürler üzerinde olumsuz etkiler yaratırken milliyetçilik düşüncesi de millet ve ulus kavramını geliştirmek için geleneksel yapılar ve tarihten faydalanmıştır. $\mathrm{Bu}$ yöntemle ulus ve milletin tarihini çok eski tarihlere götürerek ezeli bir geçmişe sahip olunduğunu göstermektir. Modernizm ve milliyetçilik, toplumlarda karşı1t eğilimlerin doğmasına neden oldu. Mehter bu noktada geleneksel olarak Türk tarihini milattan önceki devirlere kadar götürmekle birlikte Osmanlılarda Batılılaşma ile ortaya çıkan yabancılaşma, kültürel değişim ve yozlaşmalara karşı toplumsal bir karşı duruşu temsilen yeniden icat edilmiştir.

Mehter, geleneğini 1826'da kapattığına göre 1914'de gelenek icadı olarak yeniden Askeri Müze'de canlandırılmasıyla bir gelenek değil sadece bir müzede sergilenen tarihi bir objeydi. II. Meşrutiyet'ten sonra başlayan gelenek icadı diğer uygulamaların bir devamı olarak dönemin toplumsal ve siyasal ihtiyaçlarına göre geleneği temsil eden bir unsur olarak ortaya çıktı. Modern çağın sorunları olan Balkan savaşları ve yaklaşan Birinci Dünya Savaşı için toplumda vatan ve millet duygusu yaratmak için modern bir çözüm olarak ortaya çıtı.

Mehter takımının yeniden canlandırılmasında Celal Esad ve Ahmet Muhtar Paşa önemli rol aldı. Mehterhâne-i Hâkânî'nin yeniden canlandırılmasında rol alan Celal Esad, Türkçülük düşüncesine sahip olduğundan dolayı mimarlık ve müzikte bir Türk sanatı ortaya koymaya çalışan kişiliğe sahipti. Celal Esad, Türklük ideolojisini Osmanlı'nın sınırlarının ötesinde aramaktaydı. Ayrıca Askeri Müze Müdürü Ahmet Muhtar Paşa, İttihat Terakki partisinde Harbiye Nazırı olan Mahmut Şevket Paşa tarafından görevlendirildi. İttihat ve Terakki Partisi'nin parti politikası doğrultusunda hareket ederek Askeri Müze'de faaliyetlerde bulundu. Her ikisini bu noktada birleştiren yeniçeri muzikası mehter takımı oldu.

Her ne kadar mehter terimi ile tarihsel süreklilik vurgulansa da yeniden canlandırmanın ilk teşebbüsünde Batı ve gelenek iç içedir. Yeniçeri kıyafetleri giydirilmiş bir bando tarafından armonize edilen makamsal Türk müziği eserleri Batı çalgılarıyla icra edildi. Sonraki yıllarda da 
Batı müzik formlarından biri olan marş formunda eserlerden oluşan repertuarla geleneksel Türk-Osmanlı askeri müziği ve kültürünü temsil eden bir yapıya kavuşmuştur. Bu yapısıyla geleneğin bir taklidi veya devamı değil (de) sanki geleneği yenileştiren ve onaran bir durum meydana gelmiştir.

Mehter geleneği seksen sekiz yıl sonra modern çağın yeniden inşası olarak devlet eliyle inşa edilse bile bu geleneksel yapıda eski görünen ama bir o kadar yeni olan uygulamalar yapılmıştır. Geleneksel mehter hakkında kesin ve detaylı bilgi elde edebilmek zordur. $\mathrm{Bu}$ durumun birçok sebebi vardır. Bunun başlıca sebebi aradan geçen uzun yıllardan dolayı yeterli belge ve kaynağın olmamasıdır. Yeniçeri Ocağı lağıv edilirken yeniçerilikle ilgili görüldüğü için mehterhâneye ait her şey yok edildi ve unutuldu. Mehter repertuarı ve kıyafetleri hakkında yeniden canlandırmada kaynak olarak kullanılması için detaylı belge ve kaynak yetersizdi. Yeniden canlandırmada rol alan kişiler Türk müziği makam ve usul bilgisi yönünden yetersizdi. Mehter geleneğinin icra tarzı bilinmiyordu. Mehter çalgılarını çalanlar arasında özellikle nota okumasını bilen icracı bulmak zordu. Tüm bu zorluklara rağmen yeni oluşum hem tarihi izlenim veren hem de yeni bir yorum anlayışına dayalı olarak kurgulandı. 1922'den sonra ülkede yaşanan Cumhuriyet rejimi ve ulusal modern devrimler ile uyuşmadığından dolayı Osmanlı'yı ve saltanatı temsil eden Mehterhâne-i Hâkânî'nin varlığına son verildi. Hem kültürel hem de müzikal yönüyle kendi geleneğini yeniden yaratarak sonraki dönemlerde ortaya çıkan mehter takımlarına geleneksel olarak örnek oldu. Bu nedenle gelenek ile gelecek arasında önemli bir köprü görevini yaptı.

\section{KAYNAKÇA}

Ahmet Cevat (1882). Tarih-i askeri-i Osmanî : Devlet-i Âliye'nin iptidaî teşakülünden bu güne kadar vukua gelen tertibat-i askeriye ve vukuât-i harbiyesini şamildir. Kitab-i

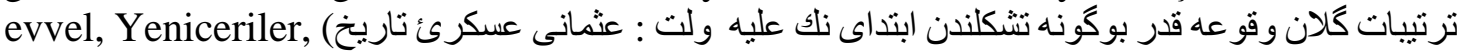
( ), Ernest Leroux, Paris.

Akşin, S. (2013), Kısa Türkiye Tarihi, Türkiye İş Bankası Kültür Yayınları, İstanbul

Ârif Paşa (1863), Mecmû'a-i Tesâvir-i Osmâniye, Tesâvir-i Efkâr Gazatehanesi Matbaası

Altınölçek, H. (1999). “Askeri Mûsiki Geleneği ve Mehterhânenin Bir Kurum Olarak Yerleşme Süreci”, Osmanlı Ansiklopedisi, c. 10, Yeni Türkiye Yayınları, Ankara.

Assmann, J. (2015). Kültürel Bellek, Ayrıntı Yayınları, İstanbul Avcı, O. (2006). "Bugüne Uzanan Yakın Çağ (1800-2000)”, Tarih El Kitabı Selçuklular'dan Bugüne, Grafiker Yayıncılık, Ankara

Ayas, G. (2015). Müzik Sosyolojisi Sorunlar-Yaklaşımlar-Tartışmalar, Doğu Kitapevi, İstanbul

Bilton, T.; Bonnet, K. ve diğerleri (2003). Introductory Sociology, Palgreva Mcmillan. Çeviri: Sosyoloji, Kemal İnal, 2008, Siyasal Yayınevi, Ankara

Büyükarman, D. A. (2008). "Vatan Kavramının Türk Tiyatro Edebiyatındaki Seyri Üzerine Bir İnceleme”, A. Ü. Türkiyat Araşturmaları Dergisi, sayı: 37, Erzurum.

Celal Esad (1911). Türk Musîkîsi ve Yeniçeri "mehter" Muzikâsı Hakkında Mütâlaat, Matbaai Hayriye, İstanbul. 
Cephanecigil, V. G. (2009). Geç Osmanlı ve Erken Cumhuriyet Dönemlerinde Mimarlık Tarihi İlgisi ve Türk Eksenli Milliyetçilik (1873-1930) (Yayınlanmamış Doktora Tezi Tez Danışmanı: Prof. Dr. Günkut AKIN), İstanbul Teknik Üniversitesi Fen Bilimler Enstitüsü.

Connerton, P. (2014). Toplumlar Nasıl Anımsar?, Ayrıntı Yayınları, İstanbul

Çoruk, A. Ş. (2016). Bir Gelenek icadı Olarak II. Meşrutiyet Döneminde Gerçekleştirilen İstanbul'un Fethi Törenleri, FSM İlmi Araştırmalar İnsan ve Toplum Bilim Dergisi, sayı: 7, İstanbul, www.dergi.fsm.edu.tr, (20.05.2017).

Çınar, H. (2006). “Osmanlılar ve Dünya (1600-1800), Tarih El Kitabı Selçuklular'da Bugüne (Editör: Ahmet Nezihi Turan), Grafiker Yayınları, Ankara.

Çoruhlu, T. (1989). “Ahmed Muhtar Paşa, Ferik”, İslam Ansiklopedisi, c. 2, TDV Yayınları, İstanbul.

Engin, V. (2003). “İlk Fetih Kutlamaları”, Popüler Tarih, sayı: 33, www.ozelburoistihbarat.com (24.05.2017)

Eralp, N. (1999). “Osmanlı'da Mehter”, Osmanlı Ansiklopedisi, c. 10, Yeni Türkiye Yayınları, Ankara.

Erendil, M. (1992). Dünden Bugüne Mehter, Genelkurmay Askeri Tarih ve Stratejik Etüt Başkanlığı Yayınları, Ankara.

Eriksen, T. H. (1993). Ethnicity and Nationalism Anthropological Perspectives, Pluto Press, London.

Ertuğ, Z. T. (2010), “Tablhâne”, İslam Ansiklopedisi, c. 39, TDV Yayınları, İstanbul.

Eyice, S. (1991). “Arseven Celal Esat”, TDV İslam Ansiklopedisi, c. 3, İstanbul.

Gazimihal, M. R. (1955). Türk Askeri Muzıkaları Tarihi, Maarif Basımevi, İstanbul

Gazimihal, M. R. (1957). Yüzyıllar Boyunca Mehterhâne ve Türk Müzik Kalkınışı, Maarif Basımevi, İstanbul

Güçtekin, N. (2014). "İsmail Hakkı Bey ve Osmanlı Devleti’nde İlk Özel Musiki Okulu: Musik-i Osmani Mektebi (1910-1920)", Rast Müzikoloji Dergisi, c. II, say1 2, file:///C:/Users/Asus/Downloads/5000120508-5000181813-1-PB., (22.06.2017)

Hanioğlu, M. Ş. (2012). “Türkçülük”, İslam Ansiklopedisi, c. 41, TDV Yayınları, İstanbul.

Halbwachs, M. (2016). Hafızanın Toplumsal Çerçeveleri, Heretik Yayınları, Ankara

Hobsbawmn, E.; Terence R. (2006). Geleneğin İcadı (Çev: Mehmet Murat Şahin), Agora Kitaplığı, İstanbul

Kaplan, A. (2005), Kültürel Müzikoloji, Bağlam Yayınları, İstanbul.

Karpat, H. K. (2008). Osmanlı Modernleşmesi Toplum Kurumsal Değişim ve Nüfus (Çeviri: Akile Zorlu Durukan, Kaan Durukan), İmge Yayınları, İstanbul

Keleş, A. (2007). Tarih Bilincimiz-Hadislerle Çöküş Sürecinde Başlatılan Tarih: İslam Tarihi, Sosyal Bilimler Araştırma Dergisi, c. 5, say1: 10,

Koçdemir, H. (1952). İstanbul'un beş yüzüncü fetih yılını kutlamağa hazırlanırken Mehterbaşı Hasan Tahsin ile bir konuşma, Vakit Gazetesi.

Kodaman, B. (2002). "II Meşrutiyet Dönemi 1908-1914)”, Türkler Ansiklopedisi, c. 8, Ankara, https://www.tarihtarih.com/?Syf=26\&Syz=286950, (22.05.2017) 
Konyalı, İ. H. (1942). İstanbul Sarayları, Bürhaneddin Matbaası, İstanbul.

Kösemihal, M. R. (1939). Türkiye- Avrupa Musiki Münasebetleri, c. 1, Nümune Matbaas1, İstanbul.

Livingston, T. E. (1999). "Music Revivals: Towards a General Theory", Ethnomusicology, vol: 43, no: 1, University of Illinois Press, www.jstor.org, (23.03.2016).

Mahmut Şevket (1909). Osmanlı Teşkilât-1 Kıyâfet-i Askeriye, Mekteb-i Harbiye Matbaası, İstanbul.

Macey, D. (2001). The Penguin of Critical Theory, Penguin Books, England.Muhammed Baha (1922), Mehter Muzikas1, Alem-i Musiki, cilt: 5, no 7, Bursa

Mehmet Zeki. (1916). Mehterhane-i Hakani ve Muzıka-yı Hümayun, Edebiyat-1 Umumiye Mecmuas1

Mülayım, S. (2009). Kronolojik Notlarıyla 19. Yüzyıl Osmanlı Müzeciliği, Osmanlı Araştırmaları XXXIV (Yayın heyeti: Halil İNALCIK- İsmail E. ERÜNSAL Heath W. LOWRY- Feridun EMECEN Klaus KREISER- BilginA YDIN), İstanbul, http://english.isam.org.tr/documents (18.05.2017)

Myers, H. (1992). Ethnomusicology An Introduction, The Macmillan Press, London.

Nora, P. (1994). Hafıza Mekanları (çev: Mehmet Emin Özcan), Dost Kitapevi, Ankara

Oransay, G. (1973). Cumhuriyetin İlk Elli Yılında Geleneksel Sanat Musikimiz, 50. Y1l kitabından ayrı basım

Öztürk, O. M. (2010). Mehter Musikisi (ed. Oğuz Elbaş), Grafiker Yayıncılık, Ankara.

Özcan, A. (2007). “Osmanlıcılık”, İ́slam Ansiklopedisi, c. 33, TDV Yayınları, İstanbul.

Özcan, N. (2003). “Mehter”, İslam Ansiklopedisi, TDV Yayınları, İstanbul.

Pakalın, M. Z. (1993). Osmanlı Tarih Deyimleri ve Terimleri Sözlüğü, c. II, MEB, İstanbul

Pertusi, A. (2004). İstanbul'un Fethi Çağdaşların Tanıklı̆̆ı, c. 1, İstanbul Fetih Cemiyeti Yayınları, İstanbul

Rauf Yekta (1912). "Mehterhâne Konseri”, Şehbal, no 50, c. 3

Sanal, H. (1964). Mehter Musikisi Bestekâr Mehterler- Mehter Havaları, Milli Eğitim Basımevi, İstanbul

Sanal, H. (1993). “Çevgân”, İslam Ansiklopedisi, TDV Yayınları, İstanbul

Şahiner, N. (1993). Mehter ve Marşları (8. Baskı), Anahtar Yayınları, İstanbul

Shaw, W. M. K. (2003). Possessors and Posssessed Museums, Archoelogy and The Visualization of History in The Late Ottoman Empire, University of California Press Berkley, Los angels, www.books.google.com, (11.09.2016)

Smith, P. (2007). Kültürel Kuram, Babil Yayınları, İstanbul

Tasouji, C. D. (2015). “Bir Hafiza Mekanı Olarak Müze: Etnografya Müzesi”, Karadeniz Teknik Üniversitesi İletişim Araştırmaları Dergisi, yıl: 3, sayı-6,

Tuğlacı, P. (1986). Mehterhane’den Bando’ya, Can Yayınları, İstanbul 
Url-1

http://www.tdk.gov.tr/index.php?option=com_bts\&view=bts\&kategori1=veritbn\&keli $\underline{\text { mesec }=163473}$

Url-2 (www.osmanligazeteleri.com/haber/istiklal-i-osmani-osmanli-bagimsizlik-gunu-buyukbir-sevkle-kutlandi-1914/279/) Erişim Tarihi: 22.05.2017

Url-3 (http://earsiv.sehir.edu.tr:8080/xmlui/bitstream/handle/11498/3997/001581784010 . pdf? sequence $=3 \&$ isAllowed $=y$ ( Erişim Tarihi: 22.06.2017

Url-4 www.altayli.net/wp

Uzun, H. (2009). “Türk Yurdu’nda 1913 Y1lı İstiklâl-i Osmanî Günü Kutlamaları”, Modern Türklük Araştırmaları Dergisi, c. 6, sayı: 1, Ankara

Vural, F. G. (2011). İslamiyet’ten Önce Türklerde Kültür ve Müzik Hun, Kök Türk ve Uygur Devletleri, Çizgi Kitabevi, Konya.

Vural, T. (2013). Türklerde Askeri Müzik Geleneği Tuğ, Nevbet, Mehter, Çizgi Kitabevi Yayınları, Konya

Vural, T. (2016). "Mehter Geleneğinin Yaşayan Kimliği”, The Journal of Academic Social Science Studies, www.dx.doi.org, (07.09.2016)

Yamak, S. (2008). "Meşrutiyetin Bayramı: 10 Temmuz Îd-i Millisi, İ. Ü. Siyasal Bilgiler Fakültesi Dergisi, no 38, İstanbul

Yaramış, A. (2013). Mehterhâne-i Âmire Ocağı'nın Islahı (1826), Sosyal Bilimler Dergisi, c. XV, say1 1, $\underline{\text { http://www.sbd.aku.edu.tr/arsiv/c15s1/c15s1b2ahmetyaramis.pdf }}$ (01.01.2017)

Y1lmaz, M. S. (2009). “Kastamonu'da İstiklal-i Osmani Günü Kutlamaları 1913-1921”, Modern Türklük Araştırmaları Dergisi, c. 6, sayı: 3, Ankara,

Wallace, A. F. C. (1956). Revitalization Movements, Willey Blackwell, www.jstor.org, (12.09.4014) 